\title{
К ВОПРОСУ О РАННЕЙ ДАТЕ ПЬЯНОБОРСКИХ ПАМЯТНИКОВ. Ч. 4-1': БРОНЗОВЫЕ НАКОНЕЧНИКИ СТРЕЛ
}

\author{
(C) 2021 г. А.А. Красноперов
}

Статья продолжает цикл публикаций, обсуждающих основания датировки начала пьяноборской культуры в Прикамье в двух аспектах: во-первых, на чем основаны утверждения о начале культуры в III в. до н.э., во-вторых, насколько привлекаемые находки соответствуют современному состоянию хронологии. Одной из категорий выступают бронзовые наконечники стрел. Как показывает распутывание цепочек ссылок, практически все они сводятся к работе М.Г. Мошковой 1962 г. и К.Ф. Смирнова 1961 г. В 1980-е гг. произошли кардинальные изменения в общей хронологии сарматских культур - при сохранении основных признаков обряда и инвентаря самих культур, изменилась дата смены раннесарматской культуры на среднесарматскую, со ІІ в. до н.э. на рубеж эр. Комплексы, датирующие признаки, «омолодились». Бронзовые наконечники стрел по-прежнему наиболее характерны для раннесарматской культуры, но сама культура по новым данным существует до нач. I в. н.э. Но, к изумлению, это никак не повлияло на хронологию местных культур. Проведенная проверка случаев, которыми оперировала М.Г. Мошкова, дополненная новыми данными, показала, что бронзовые наконечники стрел неоднократно находили в средне- и позднесарматских комплексах. В некоторых ситуациях это «амулеты» из стрел очень архаичных типов, в других, это реально использовавшиеся в быту предметы. Учитывая, что помещение стрел в погребения этих периодов в целом не характерно, утверждать, что бытование стрел строго ограничено III в. до н.э. нельзя. И ссылки на датировки 60-летней давности неприемлемы.

Ключевые слова: археология, хронология, бронзовые наконечники стрел, раннесарматская культура, среднесарматская культура, позднесарматская культура, фибула, пряжка, зеркало, меч.

\section{THE ISSUE OF THE EARLY DATING OF PIANY BOR SITES. PART 4-1: BRONZE ARROWHEADS}

\section{A.A. Krasnopeorov}

The paper continues a series of publications discussing the foundations of dating the beginning of the Piany Bor culture in the Kama region in following two aspects: first, the grounds for the statements about the beginning of the culture in the $3^{\text {rd }}$ century $\mathrm{BC}$, and secondly, to what extent the finds in question correspond to the contemporary chronology. One of the categories is represented by bronze arrowheads. According to the results of unraveling the chains of references, almost all of them come down to the work by M.G. Moshkova in 1962 and K.F. Smirnov in 1961. In the 1980s, there were cardinal changes in the general chronology of the Sarmatian cultures - while maintaining the main features of the rite and inventory of the cultures themselves, the dating of the transition of the Early Sarmatian to the Middle Sarmatian culture has changed from the $2^{\text {nd }}$ century BC to the turn of the epochs. The complexes enabling the dating of the attributes have "rejuvenated". Bronze arrowheads are still most characteristic of the Early Sarmatian culture, but the culture itself, according to new information, existed before the beginning of the $1^{\text {st }}$ century $\mathrm{AD}$. But, surprisingly, this did not affect the chronology of the local cultures. A review of the cases used by M.G. Moshkova, supplemented by new information, demonstrated that bronze arrowheads have been repeatedly found in the Middle and Late Sarmatian complexes. In certain cases, these are "amulets" made of very archaic types of arrows, and in others, these are items actually used in everyday life. Considering that the placement of arrows in burials of these periods is generally uncommon, it cannot be argued that the existence of arrows is strictly limited to the $3^{\text {rd }}$ century BC. And the dating references of 60 years ago are unacceptable.

Keywords: archaeology, chronology, bronze arrowheads, Early Sarmatian culture, Middle Sarmatian culture, Late Sarmatian culture, fibula, buckle, mirror, sword.

Важное место в аргументации ранней даты пьяноборских (и кара-абызских) памятников занимают находки наконечников стрел, бронзовых и их сочетания с железными (Зубов,

2007, с. 90). Новый виток обсуждения этой категории находок задан работами С.Э. Зубова и Р.Р. Саттарова (Зубов, 2007; Зубов, Саттаров, 2018; Саттаров, 2017; 2019д, прил. 4).

\footnotetext{
В этой части рассматриваются только находки в сарматской среде. Ввиду большого объема пьяноборские комплексы стоит обсуждать отдельно.
} 
Если первоначально в обсуждении просто перечислялись находки бронзовых наконечников в Камышлы-Тамакском I, Уяндыкском I, Кушулевском III, Юлдашевском, могильниках (Зубов, 2007, с. 93) со ссылками на ничем не обоснованные даты, то позднее акцент сместился в более предметную сферу с опорой на Кипчаковские I и II могильники.

Историография датирующих возможностей бронзовых наконечников стрел

Цепочки ссылок (Зубов, Саттаров, 2018, с. 210, 212) включают перечисление мнений К.Ф. Смирнова, А.М. Хазанова, О.И. Куринских, А.С. Скрипкина, В.М. Клепикова, А.Х. Пшеничнюка, С.В. Кузьминых, М.П. Абрамовой, В.Ю. Зуева, С.В. Демиденко ${ }^{1}$, В.А. Иванова, Б.Б. Агеева. Но в конечном счете приводят к специальной работе М.Г. Мошковой (1962).

М.Г. Мошкова представила обзор наконечников, «придерживаясь типологии и нумерации типов К.Ф. Смирнова» (1962, с. 78). Но на чем, собственно, основываются ее датировки? - ни на чем. Никаких дат не обсуждается вообще. Дважды сказано «учет остальных комплексов позволил создать дробную хронологию» $(1962$, с. 78,81$)$, но никаких вещей ни разу не названо.

Есть одна ссылка на общую периодизацию Б.Н. Гракова и косвенные упоминания вроде использования его номенклатуры. Несколько комплексов перечислено в связи с отнесением их к такой-то культуре по Б.Н. Гракову. Есть ничем не подтверждаемые фразы: «вполне определенно датируются IV в.», которые чуть позже раскрываются через типологические ряды: «ряд типов, послуживших основой для ...» (1962, с. 78$)$, а еще дальше много раз отмечено, что практически типы «существуют вплоть до III-II вв.» (1962, с. 79, четырежды). «Эталонными для самого конца IV-III вв. до н. э.» названы Прохоровские курганы (1962, с. 80). И 'датированными' внезапно оказываются случайные сборы: Баймакский р-н 1929 г., находки из насыпи (Ст. Киишки, к. 11/насыпь) и единственные находки в погребениях (Ст. Киишки, к. 11/п. 15, к. 14/п. 16) (1962, с. 81).

Касательно II в. до н. э. в основном тексте нет даже упоминаний, не говоря уж об датирующих основаниях. Список комплексов «II в. до н. э.» можно составить по подрисуночным подписям к типам VIA, VІБ, IXA, V, X, XI, XIA, XII, XIII, XVI, XVIII: Визенмиллер, к. 4/пп. 3, 4, Бережновка II, к. 85/п. 2, Бережновка ЮГ, к. 2/п. 11, В. Погромное, к. 1/п. 13, Джанатан, к. 8, Красногорское, 1903 г./п. впускн., Сайхин, к. 1 /п. 5, Ленинск, к. 3/п. 15, Ст. Киишки, к. 11/пп. 4, 12, 13, 15, 17, 19, насыпь, к. 13/пп. 13, 14, к. 14/пп. 5, 11, 16 (1962, рис. 27-30). Можно заметить, что все указанные типы датированы всеми временными отрезками, а из памятников разительно преобладают Ст. Киишки.

Т. е. из заявленного: 1) датировки прочего инвентаря не обсуждаются, 2) принятая общая периодизация теперь пересмотрена, многие комплексы получили неоднозначную оценку, 3) типы существуют долго (1962, с. $79,80)$. Реальные оценки базируются только на 4) типологических рядах, 5) «соотношении различных типов в наборе и, главное, преобладанию одного из них» $(1962$, с. 80$)$. Этого крайне мало, чтобы возводить предложенную схему в абсолют.

Показательно, что сама М.Г. Мошкова не ссылается на эти свои работы с 1980-х гг. Насколько она сохраняет актуальность сейчас? - ни насколько.

Не вдаваясь в подробности, дискуссия по датировкам Прохоровских курганов показывает, что вопрос имеет весьма неоднозначное решение. А «периодизация Б.Н. Гракова» безнадежно устарела и давно не используется, о чем есть подробный, так сказать, «внутренний» разбор (Сергацков, 1999; 2000б, с. 113; 2004, с. 107), существенные положения которого полезно повторить:

1) После выхода в 1947 г. эпохальной работы Б.Н. Гракова в отечественной археологии утвердилась и стала господствующей четырехступенчатая периодизация савромато-сарматской культуры. Именно с позиций этой концепции были написаны обобщающие, программные исследования по истории и культуре сарматов, затрагивающие, в том числе, вопросы хронологии и самого происхождения среднесарматской культуры (Смирнов, 1950 , с. $97-114 ; 1954$, с. $195-219 ; 1974$; Абрамова, 1959, с. 52-71; Мошкова, 1963, с. 8; Степи..., 1989, с. 153-202).

2) В 80-х годах оформилась новая конщепция происхождения и самого содержания среднесарматской культуры. В ее основу легли хронологические разработки А.С. Скрипкина (2006a, с. 11; 2006б, с. 136) о том, что граница между ранне- и среднесарматской культурами пролегает по рубежу эр. В I в. н. э. отмечается появление многих новаций в вещевом материале. К ним относятся украшения в полихромном зверином стиле, браслеты с несомкнутыми утолщенными концами, короткие мечи, ножны которых имеют четыре боковые 
лопасти, керамика с зооморфными ручками, тамги, китайские зеркала и зеркала с валиком по краю и коническим умбоном, бронзовые котелки с носиком-сливом или без него, с зооморфными ручками.

Из отмеченных в 1963 г. М.Г. Мошковой комплексов ${ }^{2}$, в Визенмиллер, к. 4/п. 3, Бережновка II, к. 85/п. 2, Бережновка ЮГ, к. 2/п. 11, встречены зеркала с валиками по краю типа Скрипкин-4.7, бытующие и у сармат, и в Средней Азии, и на Кавказе, и во II-I вв. до н. э. (Скрипкин, 1990, с. 151; Абрамова, 1983, с. 37; Литвинский, 1976, с. 81). А в Бережновка ЮГ, к. 2/п. 11, и вовсе найден меч с кольцевым навершием (Зуев, 1999, рис. 1, 4: 1-4, 7, с. 311, 314, 319). Красногорское, 1903 г./п. впускн., опубликован буквально только что (Зуев, 2012), из Ленинск, к. 3/п. 15, издана только глазчатая/пятнистая бусина (Мошеева, 2008, с. 31, рис. 1: 13, тип бус II до н.э. - нач. II н. э.).

Погребения Ст. Киишек по всем признакам обряда и инвентаря все еще остаются раннесарматскими, но сама раннесарматская культура (поздний этап) теперь датируется II-I вв. до н. э., до рубежа эр или сер. I в. н. э.

Находки бронзовых наконечников стрел в заведомо позднем (после III в. до н. э.) контексте

Если следовать имеющимся цепочкам ссылок, то бронзовые наконечники выходят из употребления в III в. до н. э. (Смирнов, 1961, с. 70; Мошкова, 1962, с. 82; Скрипкин, 1990, c. 134-135; Клепиков, 2002, с. 42; Клепиков, Скрипкин, 2002, с. 65; Шинкарь, 2006, с. 58; Куринских, 2011, с. 53), во II в. до н. э. встречаются лишь эпизодически.

Известны случаи находок бронзовых наконечников в памятниках Средневековья. C.А. Плетнева отметила такой в салтовских погребениях (Плетнева, 1967, с. 174, рис. 47: 16), но ссылка на комплекс указана значительно позже (Плетнева, 1989, рис. 58: 26). И другие мелкие скифские вещи встречаются в салтовских захоронениях, понятно, что хронологического смысла они не имеют.

Встречаются стрелы в комплексах гуннского времени: Беляус, гунн. могила № 3 (Дашевская, 2003, рис. 2: 9; 2014, табл. 174: 9), Паласа-Сырт, к. 2 (Котович, 1959, табл. XIII: 17; Гмыря, 2011, рис. 7: 4), Оселивка, п. 51 (Никитина, 1988, табл. 27: 4).

Какой-то единой сводки, очевидно, нет ${ }^{3}$. Но находки периодически привлекают специальное внимание (Хазанов, Черненко, 1979, с. 20-21, прим. 234; Яценко, 2007, с. 276; Шевчен- ко, 2018) или обсуждаются в связи с конкретными случаями (Глухов, 2005, с. 65 , табл. 3 ; Глебов, 2007a, с. 915; Пуздровский, 2007a, с. 67, 136; 2007б, с. 283; Глебов, Толочко, 2016, c. 46) ${ }^{6}$. Как заявлялось перед началом проекта, технической сводкой по всем сарматским культурам должна была стать серия «Статистическая обработка погребальных памятников Азиатской Сарматии». Но не стала. Есть очень жесткая развернутая критика (Зуев, 1997; 1998), есть восторженные славословия (Федоров-Давыдов, 1996). Но электронная версия так, видимо, и не появилась, вычитывать с листа и расшифровывать утомительно и времязатратно, количество ошибок при кодировке комплексов слишком велико, приходится перепроверять каждый комплекс ${ }^{7}$, многие из которых не опубликованы. Издание оказалось бессмысленной растратой сил и времени огромного коллектива людей. В истории науки останутся публикации памятников (из участвовавших в проекте это И.В. Сергацков (2000а), из не участвовавших, например, Л.С. Ильюков (Ильюков, Власкин, 1992)), а не «статистисты» на празднике археологии.

Основные сведения о выявленных находках сведены в табл. А. Очевидно, что она не полна. Вся информация перепроверялась. Ссылки на публикации приведены в таблице. Некоторые комплексы малоинформативны (Бережновка II, к. 85/п. 2, к. 100), другие дают выразительные хронологические основания. Чтобы не усложнять текст, обсуждаются только хронологически значимые сопровождающие находки, без учета керамики.

Вместе с фибулами ранне- и среднелатенской cхемьl, включая беляусский вариант, найдены в: Беляус, ск. 1, среди перемешанных костей от 20 и 13 погребений, по стратиграфическим наблюдениям О.Д. Дашевской может датироваться I в. до н. э. с допуском несколько более ранней даты (Михлин, 1980, с. 195, 197 , 201, рис. 1: 1, 2: 3, 4: 5); Неаполь, п. 39; КапакТаш, к. 1/кам. ск./п. 3. В последнем найдена и лучковая фибула II серии 4 варианта. Еще одна лучковая фибула I серии 1 варианта происходит из Битак, ск. 97. К ним примыкает комплекс Неаполь, п. 67, и Чистенькое, к. 1/п. 2. В могилах встречены наконечники ножен, железные пряжки с неподвижным крючком, веретеновидные унгвентарии (Марченко, 1996, с. 41-44, рис. 6), рогатые навершия, поясные крючки.

Фибулы раннелатенской схемы датируются 2 пол. II - нач. I в. до н. э. (Кропотов, 2010, c. 38-39), среднелатенской схемы I серии 1 
варианта - кон. II - 1 пол. I в. до н. э. (Кропотов, 2010, с. 41, 44), II серии 1 варианта - сер. I в. до н. э. - рубежом эр (Кропотов, 2010, с. 52 - № 35, c. 51).

Вместе с лучковыми фибулами найдены в: (I серии 2 варианта) Золотое, п. 91, Торгунский I, к. 1/п. 1, Усть-Альма, п. 857; (I серии 2 варианта, II серии 2 варианта, IV серии 2 варианта) Усть-Альма, ск. 92, Усть-Альма, ск. 450; (I серии 3 варианта) Тбилисская, к. 9; (I серии 3 варианта, IV серии 2 варианта) УстьАльма, ск. 43; (I серии 4 варианта) Нимфей, К26, Неаполь, п. 3; (II серии 2 варианта) УстьКаменка, к. $71^{8}$; (II серии 3 варианта) Неаполь, п. 58; (III серии - ?) Nyíregyháza-Felsősima, NE of Gyebras tanya, site 161, grave 280.

Для комплекса Битак, ск. 97, предлагалась датировка 2 пол. II - нач. I в. до н. э. (Зайцев, Мордвинцева, 2003, с. 150), что не бесспорно и вызвало возражения (Пуздровский, 2007a, с. 82-83; Кропотов, 2010, с. 51, 70).

Лучковые фибулы 1 серии 1 варианта датируются сер. І в. до н. э. - сер. I в. н. э. (Кропотов, 2010, с. 71-72), 2 варианта - сер. I - нач. II в. (Кропотов, 2010, с. 74), 3 варианта - 1 пол. - сер. II в. н. э. (Кропотов, 2010, с. 75), 4 варианта - посл. треть II - не позднее сер. III в. н. э. (Кропотов, 2010, с. 80); II серии 2 варианта - 2 пол. I - нач. II вв. н. э. (Кропотов, 2010, c. 131), 4 варианта («инкерманские») - после cep. III в. (Кропотов, 2010, с. 136); IV серии 2 варианта («лебяжьинские») - 2 пол. I - нач. II вв. н. э. (Кропотов, 2010, с. 161).

Вместе со сложнопрофилированньми фибулами найдены в: Тбилисская, к. 9, Неаполь, п. 58.

Сильнопрофилированные фибулы II серии датируются II в. Н. э., но встречаются и в нач. III в. н. э. (Скрипкин, 1977, с. 109-113; Кропотов, 2010, с. 229, 231).

Вместе с фибулами с кнопкой найдены в: Тавельские кург., 1897 г., материал сильно перемешан и при многократном использовании склепа, и в процессе хранения и включает детали уздечного набора IV в. до н. э., монеты, одна из которых определена как херсонесская III в. до н. э., Двуигольную брошь II серии со всадником, пружинную фибулу-брошь, лучковые фибулы I серии 2 варианта, поясные крючки, пряжки, браслеты со змеиными головками, кольца с выступами (Труфанов, 2004б).

Фибулы с кнопкой 1 варианта датируются 2 пол. I - нач. II в. н. э. (Кропотов, 2010, с. 213). Двуигольные броши со всадниками датируют- ся 2 пол. ІІ - І вв. до н. э. (Михлин, 1980, с. 206; Кропотов, 2010, с. 291).

Вместе с фибулами-брошами найдены в: Усть-Альма, ск. 43, форма 8, ск. 92, форма 8, ск. 450, формы 10 и 13.

Фибулы-броши формы 8 относятся к 2-3 четв. I в. н. э. (Riha, 1979, s. 183; Feugere, 1985, s. 335-344; Кропотов, 2010, с. 305), формы 10, 13 - 2 четв - cep. I в. н. э. (Riha, 1979, s. 198-199; Кропотов, 2010, с. 305).

Вместе с фибулами с завитком найдены в: Усть-Альма, ск. 43, Усть-Альма, ск. 92, УстьАльма, ск. 450, Нижнеарметовский, 1977 г.

Фибулы с завитком 1 серии датируются 2 пол. I - II вв. н. э. (Кропотов, 2010, с. 183). Общие датировки группы достаточно широки: II - 1 пол. III в. (Кропотов, 2010, с. 183, 201, 204). Для сарматских могильников Южного Урала фибулы с треугольной спинкой характерны для второй хронологической группы В.Ю. Малашева - 1 пол. - сер. III в. (Малашев, 2013, с. 104, 106).

Вместе с фибулами Авцисса найдены в: Усть-Альма, ск. 450.

Фибулы авцисса, форма 2, датируются кон. I до н. э. - 1 пол. I в. н. э. (Riha, 1979, s. 114-120; Feugere, 1985, s. 312-328; Кропотов, 2010 , c. 265).

Вместе с сильнопрофилированной фибулой с расширенной головкой найдены в: УстьАльма, п. 691.

Сильнопрофилированные фибулы с расширенной головкой датируются 2 пол. I - нач. II в. н. э. (Кропотов, 2010, с. 259).

Перечисленные типы и варианты фибул образуют 2-ю, 3-ю, и 4-ю хронологические группы фибул по В.В. Кропотову соответственно, (2) кон. І в. до н. э. - сер. І в. Н. э., период, непосредственно предшествующий широкому распространению римского импорта, (3) 2 пол. I - нач. II в. н. э., период расцвета среднесарматской культуры, (4) 2-3 четв. II в. н. э., начальный период позднесарматской культуры (Кропотов, 2010, с. 332-333, рис. 98, 98a).

Для этих могил характерны находки фаянcoвblx бусин - биноклей, скарабеев, львов, лягушек, фаллосов, кукишей, виноградных гроздей, герм, амфор, Беса; бусин Алексеева - 78, 215-217, 249, 425-426/428, 486, и др. (Алексеева, 1978; 1982; Стоянова, 2004; 2006д); амулетов (актуальная сводка - Труфанов, 2011): человечков, ажурных (Рыжова, 2005), кирок (Стоянова, 2005), ведерковидных подвесок (актуальное обсуждение - Иштванович, Кульчар, 2017); ножных браслетов и 
колец с выступами; браслетов со змеиными головками (дробная хронология - Труфанов, $2001)$; зеркал-подвесок (актуальное обсуждение - Труфанов, 2007); единично встречаются венки (Трейстер, 2014; Труфанов, Мордвинцева, 2016, с. 208), лицевые пластины (Зайцев, 2004). Очень необычный браслет, с четырьмя продольными ребрами и двумя поперечными гребнями, найден в Неаполь, п. 3. Он может иметь какое-то отношение к кругу восточноевропейских эмалей (см.: Хомякова, 2018, с. 86-94, рис. 69-79).

Антропоморфные подвески распространены в последней трети I - нач. III в. н. э. (Труфанов, 2011, с. 231-232), ажурные появляются в комплексах с посл. четверти I в. н. э. - до 1 пол. IV в. н. э. (Труфанов, 2011, с. 251-252).

Зеркала большого диаметра с валиком по краю и клиновидной ручкой (новая сводка - Глебов, 2019) наиболее популярны в начале раннесарматского периода (Глебов, 2019, c. 88), но встречаются на протяжении всей раннесарматской эпохи до I в. н. э. (Скрипкин, 1990, с. 144): постепенно меняется форма диска: с плоского (Алитуб, к. 3/п. 20) на утолщенный в центральной части (Панинардис, п. 2/1972, Алитуб, к. 26/п. 1). Зеркала-подвески (Усть-Альма, ск. 43, Панинардис, п. 2/1972, Неаполь, п. 58, Неаполь, п. 3, Кобяково, п. 329, Нижнеарметовский, 1977 г.) ранних вариантов, с коническим выступом в центре - с нач. I в. минимум до сер., но, возможно, до кон. II в. н. э. (Стоянова, 2019), без орнамента - с последней трети I в. н. э., поздние, орнаментированные - 1 пол. II - кон. III в. н. э. (Труфанов, 2007, с. 180 , рис. 6).

Подковообразные пряжки из Тавельских курганов, Усть-Альма, ск. 43, ск. 92, могут быть датированы кон. I в. до н. э. - 1 пол. I в. н. э. (Труфанов, 2004a, с. 162, 168; 20052009 , с. 214), но доживают и до нач. III в. н. э. (Масякин, 2007, с. 130). Дугоконечные пряжки Раддаи-С из Усть-Альма, ск. 92, ск. 777, вариант Б, относятся ко 2 трети -3 четв. I в. н. э. (Труфанов, 2004a, с. 168; 2005-2009, с. 217). Восьмерковидные пряжки Раддаи-U из УстьАльма, ск. 777, Койсуг, к. 4/п. 32, возможно, Усть-Лабинская, к. 35, датируются 1 пол. I в Н. э. (Труфанов, 2004a, с. 164, 168, рис. 2: 8; 2005-2009, с. 214, 217). Укороченнье дугоконечные пряжки, вариант Б (Тавельские кург.) - сер. II - нач. III в., но встречаются и позже (Труфанов, 2004a, с. 168; 2005-2009, с. 217-218; актуальное обсуждение - Костромичов, 2015).
Круглые пряжки равномерной толщины (Усть-Альма, ск. 92, Усть-Альма, ск. 43, Нимфей, К26, Лехкч-Корт, п. 1, Вербовский II, к. 8/п. 1, Октябрьский V, к. 1/п. 1, Покровка 2, к. 9/п. 1) с прямыми или чуть прогнутыми язычками существуют длительное время, но распространение получают в I-II в. н. э., c III в. передняя часть рамки начинает слегка утолщаться (Труфанов, 2005-2009, с. 218). С сер. II в. н. э. такие пряжки, тип Малашев-П1 (Усть-Альма, ск. 43, Казанская/Тифлисская, к. 42, Маляевка V, к. 7/П. 5), приобретают щиток, часто длинный (Малашев, 2000, с. 195, 209, рис. 2). На следующем этапе развития (сер. - 2 пол. III в.) появляется фасетировка, тип Малашев-П8 (Покровка 2, к. 9/П. 1), им соответствуют наконечники (Малашев, 2014, с. 139, рис. 6: 6-8). Они особенно показательны для «всаднического горизонта» раннего этапа позднесарматской культуры (Красноперов, 2019, прим. 26; актуальный обзор - Безуглов, 2017). Уже не фасетированные экземпляры с круглым щитком и прогнутым язычком, типа Малашев-П2а (Курское, п. 21, Нижнеарметовский, 1977 г.), бытуют весь III в., круглые и овальные пряжки с небольшим утолщением в передней части рамки, фасетированными язычками с уступом у основания спереди, со щитками разных форм, тип Малашев-П7 (Лехкч-Корт, п.1), распространяются во 2 пол. III в. (Малашев, 2000, с. 196). Пряжки с овальными рамками, расширенными в передней части, овальными щитками, язычками, охватывающими рамку до середины высоты, с уступом у основания сзади, тип Малашев-П10 (Суворово, ск. 38), бытуют с сер. III и весь IV в. (Малашев, 2000, с. 196; Труфанов, 20052009, с. 221).

Мечи с серповидным навериием (Бережновка ЮЗГ, к. 1/п. 11) заканчивают существование в кон. І в. до н. э. (Абрамова, 1969; 1983, c. 37; Скрипкин, 1990, с. 138; Симоненко, 2010, с. 40), с кольиевидным навершием (актуальная сводка - Скрипкин, 2005) (Ясырев III, к. 1/п. 7, Усть-Альма, ск. 777, Усть-Альма, ск. 92, Донской, к. 6/п. 23; возможно: Койсуг, к. 4/п. 32, Маляевка V, к. 7/п. 5) характерны для I - 1 пол. II в. н. э., но используются до кон. II - 1 пол. ІІІ в. до н. э. (Скрипкин, 1990, с. 124-125; Симоненко, 2010, с. 39-40; Трейстер, 2008; 2010; Лимберис, Марченко, 2020). Длинные мечи (Никольское IV, к. 1/п. 3, Лехкч-Корт, п. 1, Октябрьский $\mathrm{V}$, к. 1/п. 1), в т. ч. с насадным «изломанным» перекрестием (Усть-Альма, ск. 777) (Безуглов, 2000, с. 176; 2017, с. 95-96), 
являются показательным атрибутом позднесарматских «всаднических комплексов».

Несколько погребений среднесарматского времени отличаются исключительной выразительностью инвентаря. В Тбилисская, к. 9, найден «канделябр» (см.: Шевченко, 2006). Удила с псалиями с выступпами, в т. ч. декорированныле инкрустацией (Усть-Альма, ск. 777, Октябрьский V, к. 1/п. 1) редки (также: Новый, к. 67/П. 5, к. 71/п. 1, к. 80/п. 3, к. 80/п. 8, к. 98/п. 1, Царский, к. 64/п. 1, Воздвиженская, Нижняя Добринка, к. 2, Андреевский кург., п. 28) (Власкин, 1990; Ильюков, Власкин, 1992 , рис. 20: 1, 21: 1, 24: 2,4, 25: 7, 29: 16; Гущина, Засецкая, 1989, табл. V - кат. 48; Сергацков, Захаров, 2006; Гришаков, Зубов, 2009, рис. 22: $5)$. Такой прием украшения распространяется во 2 пол. I - нач. II в. н. э., а позже сменяется точечной расчеканкой (Гугуев, Безуглов, 1990, с. 172-173; Безуглов, Глебов, Парусимов, 2009, с. 100). В большинстве случаев эта традиция сопряжена с находками предметов «бирюзово-золотого стиля» (Усть-Лабинская, к. 35, Октябрьский V, к. 1/п. 1) (сводки - Мордвинцева, 2003; Трейстер, 2020а, рис. 2: 1, 2, с. 384-385; актуальное обсуждение - Засецкая, 2019).

Флакон относится к серии изделий I-III вв. с округлым, овальным или яйцевидным туловом, цилиндрическим, высоким или низким горлом и плотно прилегающей крышкой. В настоящее время известно более двух десятков таких находок, значительная часть которых хранится в Государственном Эрмитаже (Treister, 2004, p. 140-155, 164-179, fig. 9-31; Засецкая, 2004, с. 54, 58). Относится ко 2-й группе по классификации К.М. Скалон, с гладкой поверхностью. Все флаконы данной группы датируются в пределах I в. (Скалон, 1961, с. 138; Мимоход, Успенский, 2019, рис. с. 59: б, с. 51), но бронзовый экземпляр (Алитуб, к. 26/п. 1) является более дешевым подражанием.

Находки котлов (Алитуб, к. 3/п. 20, Октябрьский $\mathrm{V}$, к. 1/п. 1) подробно проанализированы (Демиденко, 2008).

Группу комплексов, но хронологически неоднородную, образуют находки металлической (сковорода, тазы, кувшин, стакан, ковш, ойнохоя, чаши с медальонами; сосуд с зооморфной ручкой - актуальное обсуждение: Засецкая И.П., 2011) и стеклянной: канфар (Октябрьский V, к. 1/п. 1) (Засецкая, Марченко, 1995; актуальная сводка - Трейстер, 2019в), чаша миллефиори (Алитуб, к.26/п.1) (Симоненко, 2006б), посуды (неоднократно и подробно обсуждались: Raev, 1986; Раев, 1993; Глухов, 2005, с. 16-20, 48-53; Simonenko, 2008; Симоненко, 2011; Лимберис, Марченко, 2006; Marčenko, Limberis, 2008; Трейстер, 2018a; 2018б; 2019а; 2019б; 2020б; 2020в; 2020г).

Самый поздний комплекс из до-гуннских, Суворово, ск. 38, около сер. IV в. н. э., где найдены стеклянные кувшины и чаша (Cорокина, 1965; Кунина, 1997; Шабанов, 2015, с. 223), амфоры Шелов-F (Шелов, 1978; актуальное обсуждение - Диденко, 2014), фибула Амброз-16-3/Гороховский-Б3б, пряжки Малашев-П10, зеркало с центральной петлей и ячеистым орнаментом, подвеска (щиток пряжки - ?) стиля «Закшув-Кишпек» (Шаров, 2019; библиография - Красноперов, 2019, прим. 9, 20, 21).

Наконечники стрел как хронологический индикатор

Большинство авторов, которые сталкивались с находками «ранних» наконечников стрел в «поздних» комплексах, автоматически причисляли их к амулетам (Сымонович, 1983, c. 85; Скрипкин, 1990, с. 74; 2000, с. 1449; Дашевская, $1991^{10}$, с. 34; Гущина, Засецкая, 1994, с. 10, 23; Юрочкин, Труфанов, 2003, с. 204; Шинкарь ${ }^{11}$, 2006, с. 59; 2007; Пуздровский, 2007б, с. 283; Горбенко, Косяненко, 2011, с. 89, 163; Глебов, Толочко, 2016, с. 46, $55^{12}$ ) без обсуждения типа и контекста находки. Источником такой уверенности были устойчивые штампы об «окончательной замене бронзовых наконечников железными ко II в. до н. э.» (Смирнов, 1961, с. 70; Мошкова, 1962, с. 82; Скрипкин, 1990, с. 134-135; Клепиков, 2002, с. 42; Клепиков, Скрипкин, 2002, с. 65; Шинкарь, 2006, с. 58).

Отрицать типологическую динамику наконечников не приходится, она очевидна: исчезновение шипа и постепенное удлинение головки у втульчатых и замещение их черешковыми. Это подтверждается неоднократными наблюдениями над соотношением типов в наборах. Но откуда такая уверенность в хронологии событий?

Прежде всего - находки не единичны. И списывать такое количество исключительно на амулеты уже затруднительно. Бесспорно, ранними являются наконечники с шипом, периодически встречающиеся в среднесарматских комплексах. В ряде случаев зафиксировано их нахождение среди скоплений амулетов: Соколова Могила (Ковпаненко, 1986, рис. 100: 6, 101: 7), Алитуб, к. 3/п. 20, Алитуб, к. 26/п. 1, Тбилисская, к. 9, края подпилены (Ждановский, 1984, с. 87), Тифлисская, к. 20, 
и т. д. В других стрелы определенно использовались как боевые: Танаис, п. 1/Н3/1996, найден с остатком древка в колчане вместе с железными втульчатыми (Глебов, Ильяшенко, Толочко, 2004, с. 293, 295), Битак, ск. 97 (Зайцев, Мордвинцева, 2003, с. 149), Nyíregyháza-Felsősima, NE of Gyebras tanya, site 161, grave 280, Nyíregyháza-Oros (Istvánovits, Kulcsár, 2014, p. 145).

Промежуточный вывод № 1: Апелляции к просто находкам бронзовых стрел не работают. Всегда обязательна характеристика типа. Ранняя хронологическая позиция каких-то типов возражений не вызывает, другие имеют продолжительное время бытования.

Для примера хронологии ${ }^{13}$ можно обратиться к наиболее ярким комплексам, с находками римской бронзовой посуды. Разница во времени производства вещей из Алитуб, к. 26/п. 1, вызвала обширную дискуссию (Раев, 2006, с. 93-95; Симоненко, 2006а, с. 103-107, рис. 1): по мнению Б.А. Раева, с учетом неточной атрибуции монет, - нач. 2 пол. I в. н. э. (Raev, 1986, p. 10, 48); А.В. Симоненко, с опорой на аналогии стеклянной чаше, - кон. I до н. э. - нач. I в. н. э. (Симоненко, 2011, с. 74); М.Ю. Трейстер, основываясь на находках ковшей Эггерс-136, - тем же временем (Трейстер, 2020б, с. 36-37). Монеты из комплекса подробно разбирал С.И. Безуглов, отметивший их редкость и принадлежность к хронологическому интервалу с 12 г. до н. э. по 14 г. н. э. - времени появления статеров с монограммой ВАР, принадлежащих чекану Аспурга (Безуглов, 2001). Очень жестко с историческими событиями иберо-парфянской войны 35 г. связывает поступление вещей в Октябрьский V, к. 1/п. 1 (и некоторые другие памятники), М.Ю. Трейстер: серебряные чаши не позднее 1 пол. I в. до н. э., в пределах I в. до н. э. следует датировать бронзовый таз с литыми ножками в форме катушек и атташами ручек в виде масок Силена, стеклянный скифос 1 пол. I в. н. э. (Трейстер, 2018б, с. 150), что встречает не менее жесткие возражения (Балахванцев, 2020). Предполагается, что либо в Усть-Альма, ск. 844, было два погребения разного времени (одно - с бронзовым сервизом из ойнохои и патеры, датирующееся сер. - 3 четв. I в. н. э., а второе - с кувшином, совершенное в последней четв. I или на рубеже I-II вв. н. э.), либо это было одно погребение, датируемое 3 четв. I в. н. э. (Пуздровский, 2005-2009, с. 337). Но наборы из ойнохои типа Миллинген и патеры типа Кентрбери, хотя и появились еще во 2 четв. I в. н. э., но были распространены и во
II и встречались даже в комплексах III в. Н. э. (Трейстер, 2018a, с. 221-222).

Промежуточный вывод №2: Апелляции к просто находкам бронзовых стрел не работают. Всегда обязателен контекст находки. Единичный экземпляр может запаздывать на произвольное время. Наборы стрел, вероятно, должны быть более точны.

Для населения средне- и позднесарматского времени в рассмотренных регионах в принципе не характерно помещение стрел в погребения (Кожухов, 1994, с. 11 - цит. по: Малышев, 2008, с. 160; Симоненко, 2010, с. 104, 106; Кривошеев, 2005д, с. 132; Малашев, 2013д, с. 85, 87-88). Это особенно заметно в сопоставлении с количеством находок мечей. Но заподозрить, что оружие дальнего боя было полностью исключено, невозможно. Стрелы нужны хотя бы для охоты: трудно ходить на птицу и быстрого зверя с коротким мечом. А железные втульчатые наконечники в Предкавказье, на Кубани, даже на Дону, продолжают использоваться до I в. н. э. (Петренко, 1992, с. 33; Абрамова, 1993, с. 74-76, 148; Марченко, 196, с. 57-67; Глебов, 2017, с. 55). Показательна ситуация на Кавказе ${ }^{14}$, где мелкие железные втульчатые двухлопастные наконечники с треугольной головкой и костяные втульчатые четрехгранные с треугольной головкой зафиксированы в комплексах 1 пол. III в. н. э. Обе разновидности не имеют аналогий в синхронных степных памятниках, что дало возможность В.Ю. Малашеву предположить существование локальных региональных серий (Малашев, 2016, с. 37-38). Аналогично на Венгерской Равнине, где количество находок уже достаточно, чтобы говорить о регулярности использования «скифских» стрел сарматами в римское время (Istvánovits, Kulcsár, 2014, p. 145, 148).

Отсутствие стрел в могилах - все-таки - обрядовая черта (см.: Симоненко, 2010, с. 106). Но отсутствие не дает возможность описать типы, бытующие в живой культуре. Однако и не должно позволять утверждать, что типы более раннего времени прекратили свое существование. Отсутствие чего-либо это лишь отсутствие информации об объекте (категории находок).

Промежуточный вывод № 3: Стрелы - функциональный инвентарь. Они должны быть эффективными и не обязаны быть модными. Нахождение «эффективной формы» стабилизирует тип функционального инвентаря на столетия: этнографический нож не сильно отличается от ножа железного века. 
Это не позволяет абсолютизировать хронологические возможности таких вещей.

Еще раз нужно подчеркнуть: 1) находки бронзовых наконечников в позднем контексте не единичны; 2) стрелы в составе погребального инвентаря для средне- и позднесарматского времени не характерны; 3) зафиксированы (Танаис, п. 1/Н3/1996) случаи одновременного использования в колчане

\section{Примечания:}

${ }^{1}$ Самостоятельное мнение из перечисленных у В.Ю. Зуева (1999, с. 321-322; 2004, с. 217-218) и С.В. Демиденко (2007), которые не переписывали, а рассмотрели конкретные находки.

${ }^{2}$ Ёмкую характеристику дал В.Ю. Зуев: «Для памятников прохоровской культуры мы практически не имеем полноценно изданных археологических комплексов. В публикациях комплексы иллюстративно раскладывались по категориям находок: в одну таблицу помещались наконечники стрел, в другую - керамика, в третью - мечи и кинжалы, и т.д. Словесные описания сопровождались выборочными иллюстрациями, дающими лишь общее представление о типах находок» (Зуев, 2000, с. 99).

Та же ситуация относится ко многим другим периодам и территориям.

3 Эта работа не смогла бы состояться без помощи щедро делившихся литературой: Д.Г. Бугрова (Казань), И.В. Толочко (Ростов-на-Дону), Д.А. Топала (Кишинев), О.А. Щегловой (Санкт-Петербург), И.О. Гавритухина (Москва).

${ }^{4}$ Упоминаются также Ордынский бугор, к. 1, В. Погромное, к. 6/п. 8 - оба со ссылками на отчеты, и Аткарский, к. 11, эту публикацию найти не удалось.

5 Упоминаются также Подгорненский IV, к. 30/п. 7, Подгорненский I, к. 1/п. 9 - без прямых ссылок. Из Подгорненский I, к. 1/п. 9 и Подгорненский IV, к. 30/п. 7 опубликованы только зеркала с валиком по краю и плоское (Глебов, 2019, рис. 3: 8, 1: 5) и сосуд (Глебов, 2007б, рис. 6: 15).

${ }^{6}$ Мне остались недоступны две публикации (Шевченко, 1993; Ждановский, 1988).

${ }^{7}$ Втульчатые стрелы кодируются 31С, бронзовые - 32В (Среднесарматская культура, 2002, с. 31). Комплекс 415/1 - Новый, к. 46/п. 2. Опубликован (Ильюков, Власкин, 1992, с. 59, рис. 12), таких стрел нет. Зато стрелы есть в Усть-Лабинская, к. 35 (Гущина, Засецкая, 1994, кат. 403) - 814/1, Тифлисская, к. 20 (Гущина, Засецкая, 1994, кат. 319) - 805/1, что никак не отмечено в «статистике».

${ }^{8}$ Наконечник стрелы найден на уровне горизонта в засыпи.

9 Упомянуты находки: Бережновка I, к. 35/п. 17, Белокаменка, к. 7/п. 3. В действительности это к. 3/п. 7 (Клепиков, 2002, рис. 7: 45, 11: 11, 29: 8, 30: 15). Оба комплекса - раннего времени.

${ }^{10}$ О.Д. Дашевская указывает находки в имении Талаевой, раскопки 1895 г. (ОАК за 1895 г., 1897, с. 1415). Комплекс долгое время был известен только по неопределимому описанию: лепной сосуд, браслет, бусы (Дашевская, 1991, табл. 60: 7, с. 53 - №23). Материал недавно опубликовали С.Г. Колтухов и С.Н. Сенаторов (2016, № 22, с. 91-93, рис. 31: 1-3). По их мнению, могила относится к IV в. до н. э. (2016, с. 93), но основания для какой-либо датировки, ввиду невыразительности, не очень убедительные.

${ }^{11}$ Упомянуты находки: Кривая Лука VII, к. 9/п. 6 (убит стрелой), Кривая Лука VIII, к. 1/п. 10, к. 8/п. 15, Кулешовка, к. 1/п. 17, Красногоровка I, к. 22/п. 10, Ильевка, к. 4/п. 2, Старица, к. 36/п. 1, Соленое Займище, к. 10/п. 7, Ясырев I, к. 8/п. 9. В последнем случае погребение до железного века, наконечник кремневый (Мошкова, Федорова-Давыдова, 1974, с. 49). Соленое Займище, к. 10/п. 7 (Дьяченко, Железчиков, 1995, с. 160, рис. 6: 1,6,7), раннего времени, как и Кулешовка, к. 1/п. 17, откуда удалось найти короткий меч с серповидным навершием без перекрестья (Скрипкин, 1990, рис. 17: 17, 20: 16). Из Ильевка, к. 4/п. 2, изданы сосуд и зеркало (Скрипкин, 1990, рис. 14: 11, 35: 18). Остальные не опубликованы.

12 Этим обстоятельством объяснено исключение находок единичных наконечников из каталога «женских раннесарматских погребений с оружием» (Глебов, Толочко, 2016, с. 55 - прим.2). Это была бы очень интересная сводка, крайне полезная и для этой работы.

${ }^{13}$ Хронология крымских могильников много лет разрабатывается А.А. Труфановым. В сжатом варианте с перечислением конкретных комплексов и дат можно увидеть в: (Труфанов, 2011, с. 260-265, табл. 1).

${ }^{14}$ М.П. Абрамова указывает на находки бронзовых наконечников стрел в Нижнеджулатском, Ханкальском, Комаровском, Грушевском могильниках (Абрамова, 1993, с. 68, 74), но без номеров комплексов и ссылок.

\section{ЛИТЕРАТУРА}

Абрамова М.П. Сарматская культура II в. до н.э. - І в. н.э. (По материалам Нижнего Поволжья. Сусловский этап) // СА. 1959. №1. С. 52-71.

Абрамова М.П. Мечи и кинжалы центральных районов Северного Кавказа в сарматское время // Древности Восточной Европы. К 70-летию А.П. Смирнова / МИА. №169 / Отв. ред. Л.А. Евтюхова. М.: Наука, 1969. С. 3-10. 
Абрамова М.П. О хронологии ранней группы погребений Нижне-Джулатского могильника // КСИА. Вып. 176. М.: Наука, 1983. С. 34-40.

Абрамова М.П. Центральное Предкавказье в сарматское время (III в. до. н.э. - IV в. н.э.) // Археология эпохи великого переселения народов и раннего средневековья. Вып. 2 / Отв. ред. серии Г.Е. Афанасьев и Ф. Дайм при участии Д. Кидда. М.: ИА РАН, 1993. 240 с.

Алексеева Е.М. Античные бусы Северного Причерноморья / САИ. Вып. ГІ-12. М.: Наука, 1978. 120 с. Алексеева Е.М. Античные бусы Северного Причерноморья / САИ. Вып. Г1-12. М.: Наука, 1982. 105 с. Арсеньева T.M. Могильник у деревни Ново-Отрадное // Поселения и могильники Керченского полуострова начала н.э. / МИА. №155 / Отв. ред. А.И. Мелюкова. М.: Наука, 1970. С. 82-149.

Бабенчиков В.П. Некрополь Неаполя скифского // История и археология древнего Крыма / Отв. ред. П.Н. Шульц. Киев: АН УССР, 1957. С. 94-141.

Балахванцев А.С. Сарматские походы в Закавказье: мифы и реальность // Археологическое наследие Кавказа: актуальные проблемы изучения и сохранения. Материалы международной научн.конф. «XXXI Крупновские чтения» / Отв. ред. М.С. Гаджиев. Махачкала, 2020. С. 184-186.

Безуглов С.И. Позднесарматские мечи (по материалам Подонья) // Сарматы и их соседи на Дону / Материалы и исследования по археологии Дона. Вып. 1 / Отв. ред. Ю. К. Гугуев. Ростов на-Дону: Teppa, 2000. C. 169-193.

Безуглов С.И. Находки античных монет в погребениях кочевников на Нижнем Дону // Донская археология. 2001. №1-2. С. 57-61.

Безуглов С.И. Позднесарматский курган у станицы Камышевской на Дону // Вестник Танаиса. Вып. 4 / Научн.ред. С.М. Ильяшенко. Недвиговка, 2017. С. 84-147.

Безуглов С.И., Глебов В.П., Парусимов И.Н. Позднесарматские погребения в устье Дона (курганный могильник Валовый I). Ростов-на-Дону: Медиа-Полис, 2009. 128 с.

Baдаи A.X., Кульчар B. К вопросу о так называемых сарматских пряжках // ААН. Т.36. 1984. S. 239-261.

Виноградов В.Б., Петренко В.А. Могильник сарматской эпохи на горе Лехкч-Корт (юго-восточная Чечня) // СА. 1974. №1. С. 171-180.

Власкин В.М. Уздечный набор с тамгообразными псалиями из могильника «Новый» // ИАИАНД в 1989 г. Вып. 9 / Отв. ред. В.Е. Максименко. Азов, 1990. С. 64-68.

Высотская T.Н. Усть-Альминское городище и некрополь. Киев: Киевская Академия Евробизнеса, 1994. $207 \mathrm{c}$.

Глебов В.П. Вооружение и военное дело кочевников нижнего Подонья раннесарматского времени (II-I вв. до н.э.) // Вооружение сарматов: региональная типология и хронология / Отв. ред. Л.Т. Яблонский, А.Д. Таиров. Челябинск: ЮУрГУ, 2007а. С. 88-98.

Глебов В.П. Специфика становления раннесарматской культуры на нижнем Дону // Региональные особенности раннесарматской культуры. Мат-лы семинара. Вып. II / Отв. ред. И.В. Сергацков. Волгоград: ВолГУ, 2007б. С. 59-82.

Глебов В.П. Сираки на Дону. О погребениях предкавказского облика II-I вв. до н.э. в Нижнем Подонье // VII «Анфимовские чтения» по археологии западного Кавказа. Социально-экономическое развитие населения западного Кавказа в древности ти средневековье. Мат-лы Международн. научн.конф. (г.Краснодар, 31 мая - 2 июня 2017 г.) / Ред.колл. Р.Б. Схатум. Краснодар: ИП Смородин, 2017. С. 53-62.

Глебов В.П. Зеркала раннесарматской культуры нижнего Подонья // НАВ. 2019. Т.18. №2 . С. 86-104.

Глебов В.П., Ильяменко С. М., Толочко И.В. Оружие из некрополя Танаиса эллинистического времени // Боспорский феномен: проблемы хронологии и датировки памятников. Ч.1 / Отв. ред. В.Ю. Зуев. СПб.: ГЭ, 2004. С. 292-307.

Глебов В.П., Толочко И.В. Женские погребения с оружием на нижнем Дону в эпоху позднего эллинизма: Танаис и сарматы // Античная цивилизация и варварский мир Понто-Каспийского региона: мат-лы Всероссийской научн.конф. с международным участием, посвящ. 70-летнему юбилею Б.А. Раева (Кагальник, 20-21 октября 2016 г.) / Отв. ред. С.И. Лукьяшко. Ростов-на-Дону: ЮНЦ РАН, 2016. C. 44-84.

Глухов А.А. Сарматы междуречья Волги и Дона в I - первой половине II в. н.э. Волгоград: Волгоградское научное изд-во, 2005. $238 \mathrm{c}$.

Гмыря Л.Б. Паласа-Сыртский курганный могильник IV-V вв.: 130 лет исследований // Вестник ИИАЭ. 2011. №4. С. 36-80.

Горбенко А.А., Косяненко В.М. Некрополь Паниардиса (Крепостного городища) / Донские древности. Вып. 11. Азов: Азов. музей-заповедник, 2011. 512 с.

Грач Н.Л. Некрополь Нимфея. СПб.: Наука, 1999. 328 с.

Гришаков В.В., Зубов С.Э. Андреевский курган в системе археологических культур раннего железного века Восточной Европы / Археология евразийских степей. Вып. 7. Казань: Институт Истории им. Ш. Марджани АН РТ; Самарский муниципальный институт управления, 2009. 173 с. 
Гугуев В.К., Безуглов С.И. Всадническое погребение первых веков нашей эры из курганного некрополя Кобякова городища на Дону // СА. 1990. №2. С. 164-175.

Гущина И.И., Засеикая И.П. Погребения зубовско-воздвиженского типа из раскопок Н.И. Веселовского в Прикубанье (І в. до н.э. - нач. ІІ в. н.э.) // Археологические исследования на юге Восточной Европы / Труды ГИМ. Вып. 70 / Отв. ред. М.П. Абрамова. М.: Наука, 1989. С. 71-141.

Гущина И.И., Засеикая И.П. «Золотое кладбище» Римской эпохи в Прикубанье / Российская археологическая библиотека. Вып. 1. СПб.: Фарн, 1994. 172 с.

Дашевская О.Д. Поздние скифы в Крыму / САИ. Вып. Д1-7. М.: Наука, 1991. 142 с.

Дашевская О.Д. Третье захоронение гуннского времени на Беляусе // РА. 2003. №1. С. 160-163.

Дамевская О.Д. Некрополь Беляуса. Симферополь: Предприятие Феникс, 2014. 284 с.

Дворниченко В.В., Малиновская Н.В., Федоров-Давыдов Г.А. Раскопки курганов в урочище Кривая Лука в 1973 г. // Древности Астраханского края / Труды Поволжской АЭ. Вып. 4 / Отв. ред. Г.А. Федоров-Давыдов. М.: Наука, 1977. С. 3-78, 83-194.

Дворниченко В.В., Федоров-Давыдов Г.А. Раскопки курганов в зоне строительства Калмыцко-Астраханской и Никольской рисовых оросительных систем // Сокровища сарматских вождей и древние города Поволжья / Отв. ред. К.А. Смирнов. М.: Наука, 1989. С. 14-132.

Демиденко C.В. Об одном из аспектов «проблемы III в. до н.э.» в сарматской археологии // РА. 2007. №2. C. $48-54$.

Демиденко С.В. Бронзовые котлы древних племен Нижнего Поволжья и Южного Приуралья (V в до н.э. - III в. н.э.). M: URSS, 2008. 328 с., цв. ил.

Демиденко С.В. Новые исследования памятников ранних кочевников в низовьях Торгуна и Еруслана // Всадники Великой степи: традиции и новации / Труды филиала Института археологии им. А.X. Маргулана в г. Астана. T. IV / Науч. ред. А. Онгар. Астана: ФИА им. А.Х. Маргулана в г. Астана, 2014.. C. $8-21$.

Диденко С.В. Хронология светлоглиняных узкогорлых амфор типов Шелов D и $\mathrm{F}$ (по материалам погребальных комплексов) // Черняхівська культура: до 120-річчя від дня народження В.П. Петрова / OIUM. №4 / Відп.ред. О.В. Петраускас, С.А. Горбаненко. К.: Інститут археології НАН України, 2014. C. 34-48.

Дьяченко А.Н., Железчиков Б.Ф. Раскопки могильной группы у села Соленое Займище // Донские древности. Вып. 4 / Отв. ред. С.И. Лукьяшко. Азов, 1995, С. 149-168.

Ждановский А.М. Подкурганные катакомбы Среднего Прикубанья первых веков нашей эры // Археолого-этнографические исследования Северного Кавказа / Отв. ред. Н. И. Кирей. Краснодар: КубГУ, 1984. С. 72-99.

Ждановский А.М. Классификация наконечников стрел курганных погребений Среднего Прикубанья сарматского времени // Проблемы археологии и этнографии Северного Кавказа / Под ред. В.Б. Виноградова. Краснодар: КГУ, 1988. С. 54-68.

Зайщев Ю.П. Скилур и его царство (Новые открытия и новые проблемы) // ВДИ. 1999. №3. C. $127-148$.

Зайщев Ю.П. Золотые «лицевые» пластины в позднескифской культуре Крыма // Ювелирное искусство и материальная культура. Тез. докл. участников тринадцатого коллоквиума (12-18 апреля 2004 г.). / Сост. Н.А. Захарова. СПб: ГЭ, 2004. С. 47-50.

Зайцев Ю.П., Мордвинцева В.И. Подвязные фибулы в варварских погребениях Северного Причерноморья позднеэллинистического периода // РА. 2003. №2. С. 135-154.

Засеикая И.П. Золотой флакон сарматской эпохи // СГЭ. Вып. LXII. СПб.: ГЭ, 2004. C. 54-61.

Засеикая И.П. Сокровища кургана Хохлач. Новочеркасский клад. СПб.: Эрмитаж, 2011. 328 с.

Засеикая И.П. Искусство звериного стиля сарматской эпохи (II в. до н.э. - начало II в. н.э.). Симферополь: «Антиква». 2019. 184 с.

Засеикая И.П., Ильюков Л.С., Косяненко В.М. Погребальный комплекс среднесарматской культуры у хут.Алитуб // Донская археология. 1999. №2. С. 51-60.

Засеикая И.П., Марченко И.И. Классификация стеклянных канфаров позднеэллинистического и раннеримского времени // АСГЭ. Вып. 32 / Ред. М.Б. Щукин. СПб.: ГЭ, 1995. С. 90-104.

Захаров А.В. Сарматское погребение в кургане «Крестовый» // Сарматы и их соседи на Дону / Материалы и исследования по археологии Дона. Вып. 1 / Отв. ред. Ю. К. Гугуев. Ростов на-Дону: Терра, 2000. C. $27-45$.

Зубов С.Э. Хроноиндикаторы раннепьяноборских могильников Икско-Бельского междуречья // Проблемы археологии Нижнего Поволжья. II Междунар. Нижневолж. Археол. Конф., г. Волгоград, 12-15 нояб. 2007 г.: тез. докл. / Отв. ред. А. В. Кияшко, А. С. Скрипкин. Волгоград: ВолГУ, 2007. С. $87-96$.

Зубов С.Э., Саттаров Р.P. Наконечники стрел пьяноборской культуры как хронологические маркеры (по материалам погребальных комплексов Кипчаковского I курганно-грунтового могильника) // XXI Уральское археологическое совещание, посвящ. 85-летию со дня рожд. Г.И. Матвеевой и 70-летию со 
дня рожд. И.Б. Васильева. Мат-лы Всероссийской научн.конф. с международным участием. Самара: СГСПУ; ООО «Порто-принт», 2018. С. 210-214.

Зуев В.Ю. К вопросу о «савроматской» культуре. СПб.: ГЭ, 1997. 42 с.

Зуев В.Ю. Раннесарматская культура IV-III вв. до н.э. Статистический феномен и археологическая реальность (По поводу кн.: Стат. обраб. погреб. памятников Азиат. Сарматии. Вып. II. Раннесарм. культура. М.: ИА РАН, 1997. 277 с.) СПб.: [б. и.], 1998. 41 с.

Зуев В.Ю. О путях решения «проблемы III в. до н.э.» в периодизации археологических памятников сарматской эпохи // Stratum plus. 1999. №3. С. 305-324.

Зуев В.Ю. Основные проблемы хронологии «раннесарматской» культуры // Раннесарматская культура: формирование, развитие, хронология. Материалы IV международной конференции «Проблемы сарматской археологии и истории». Вып. 1. / Отв. ред. В.Н. Мышкин. Самара: СНЦ РАН, 2000. С. 85-104.

Зуев В.Ю. Среднесарматские и позднесарматские памятники на территории южного Приуралья // Сарматские культуры Евразии: проблемы региональной хронологии. Доклады к 5 межд. конф. «Проблемы сарматской археологии и истории» / Отв. ред. Б.А. Раев. Краснодар: Фирма НСС, 2004. С. 205-220.

Зуев В.Ю. Красногорский курган // Золото, конь и человек. Сб.ст. к 60-летию А.В. Симоненко./ Отв. ред. Кривенко О. А. К.: Скиф, 2012. С. 385-410.

Ильюков Л.С., Власкин М.В. Сарматы междуречья Сала и Маныча. Ростов-на-Дону: Ростовский ун-т, 1992. $288 \mathrm{c.}$

Иитванович Э., Кульчар В. Ведерковидные подвески в сарматском Барбарикуме карпатского бассейна (1-5 вв. н.э.) // Свропейська археологія I тисячоліття н.е.: Збірник наукових праць на честь Л.В. Вакуленко / Відп.ред. А.В. Скиба, С.А. Горбаненко. К., 2017. С. 51-62.

Клепиков В.M. Сарматы Нижнего Поволжья в IV-III вв. до н.э. Волгоград: ВолГУ, 2002. 216 с.

Клепиков В.М., Скрипкин А.С. Хронология раннесарматских памятников Нижнего Поволжья // НАВ. Вып. 5. / Отв. ред. А.С. Скрипкин. Волгоград: ВолГУ. 2002. С. 47-81.

Ковпаненко Г.Т. Сарматское погребение I века н. э. на Южном Буге. Киев: Наукова думка, 1986. 145 с. Колтухов С.Г., Сенаторов С.Н. Скифы Предгорного Крыма в VII-IV вв. до н. э. Курганы 1890-1892 и 1895 гг. (по материалам Н.И. Веселовского и Ю.А. Кулаковского) / Материалы к археологической карте Крыма. Вып. XVII. Симферополь: ИП Бровка А.А., 2016. 288 с.

Колтухов С.Г., Тощев Г.Н. Курганные древности Крыма. Вып. 2. Запорожье, 1998. 194 с.

Корпусова В.Н. Некрополь Золотое. К этнокультурной истории европейского Боспора. К.: Наукова думка, 1983. 184 с.

Костенко В.И. Сарматы в Нижнем Поднепровье по материалам Усть-Каменского могильника. Днепропетровск: ДДУ, 1993. 152 с.

Костромичев Д.А. Ажурные пряжки с пельтовижной рамкой: вопросы типологии, хронологии и происхождения // Stratum plus. 2015. №4. С. 299-356.

Котович В.Г. Новые археологические памятники южного Дагестана // МАД. Т.1. / Отв. ред. Г.Д. Даниялов. Махачкала: Даг. кн. изд-во, 1959. С. 121-156.

Красноперов А.А. Пряжка из Бродовского могильника (Прикамье) в контексте полихромных стилей // Лесная и лесостепная зоны Восточной Европы в эпохи римских влияний и Великого переселения народов. Конференция 4. Ч. ІІ / Ред. И.О. Гавритухин, А.М. Воронцов, Тула: гос. музей-заповедник «Куликово поле», 2019. С. 103-190.

Красноперов А.А., Бахшиев И.И. Материалы Нижнеарметовского могильника позднесарматского времени из музейных собраний Башкирии // Томский журнал лингвистических и антропологических исследований. 2019. Вып. 3 (25). С. 104-115.

Кривошеев М.В. Позднесарматская культура южной части междуречья Волги и Дона. Проблемы хронологии и периодизации. Дисс. ... канд. истор. наук. Волгоград, 2005д. 321 с.

Кропотов В.В. Фибулы сарматской эпохи. Киев: АДЕФ-Украина, 2010. 384 с.

Кунина Н.3. Античное стекло в собрании Эрмитажа. СПб: Арс, 1997. 360 с.

Куринских О.И. Наконечники стрел ранних кочевников Левобережного Илека VI-I вв. до н.э. (по материалам могильников у с. Покровка) // РА. 2011. №3. С. 42-54.

Ларенок В.А. Меотские древности. Каталог погребальных комплексов некрополя Кобякова городища из раскопок 1999-2000 гг. Ч.1. Ростов-на-Дону: Донской ИД, 2013. 448 с.

Лимберис Н.Ю., Марченко И.И. Стекло миллефиори в сарматских погребениях // Liber Archaeologicae: сборник статей, посвящ. 60-летию Б.А. Раева / Ред. А.В. Симоненко. Краснодар, 2006. С. 51-77.

Лимберис Н.Ю., Марченко И.И. Хронология мечей с кольцевым навершием из меотских памятников правобережья Кубани // НАВ. 2020. Т.19. №2. С. 164-182.

Литвинский Б.А. Орудия труда и утварь из могильников Западной Ферганы (Археологические и этнографические материалы по истории культуры и религии Средней Азии) / Могильники западной Ферганы. IV. М.: Наука, 1978. 216 с.

Максименко B.E. Сарматские погребения в дельте Дона // СА. 1970. №2. С. 224-232. 
Максименко B.Е. Савроматы и сарматы на Нижнем Дону. Ростов-на-Дону: Рост. ун-т, 1983. 224 с.

Малашев В.Ю. Периодизация ременных гарнитур позднесарматского времени // Сарматы и их соседи на Дону / Материалы и исследования по археологии Дона. Вып. 1 / Отв. ред. Ю. К. Гугуев. Ростов на-Дону: Терра, 2000. С. 194-232.

Малашев В.Ю. Позднесарматская культура Южного Приуралья во II-III вв. н.э. Дисс. ... канд. ист. наук. М., 2013д. 301 с.

Малашев В.Ю. Некоторые аспекты контактов носителей позднесарматской культуры южноуральских степей с населением лесной и лесостепной полосы Поволжья и Приуралья // УАВ. 2014. №14. C. $130-140$.

Малашев В.Ю. Памятники среднесарматской культуры северо-кавказских степей и их традиции в курганных могильниках Северо-Восточного Кавказа второй половины II - середины V в. н.э. М.: ИА PAH, 2016. 208 c.

Мальщшев А.А. Погребальный инвентарь цемдолинского некрополя // Аспургиане на юго-востоке азиатского Боспора: по материалам Цемдолинского некрополя / Отв. ред. А.А. Малышев. М.: Гриф и K, 2008. С. 136-180.

Мамонтов В.И. Курганный могильник Шебалино // Древности Волго-Донских степей. Вып. 5. Волгоград: Перемена, 1995. С. 20-33.

Мамонтов В.И. Древнее население левобережья Дона (по материалам курганного могильника Первомайский VII). Волгоград: ВолГУ, 2000. 149 с.

Мамонтов В.И. Сарматские погребения из курганного могильника Вербовский II // НАВ. Вып. 9. Волгоград: ВолГУ, 2008. С. 170-197.

Марченко И.И. Сираки Кубани (По материалам курганных погребений Нижней Кубани). Краснодар: б/и, 1996. 336 с.

Масякин B.B. Римские фибулы и детали ременной гарнитуры из некрополя Заветное // Древняя Таврика. Посвящ. 80-летию Т.Н. Высотской / Общ.ред. Ю.П. Зайцев, В.И. Мордвинцева. Симферополь: Универсум, 2007. С. 125-138.

Мимоход Р.А., Успенский П.С. Курганные могильники на Нижнем Дону // Новые археологические проекты: Воссоздавая прошлое / Под ред. Н.А. Макарова. М.: ИА РАН, 2019. С. 58-61.

Михеев В.К. Подонье в составе Хазарского каганата. Харьков, 1985. 148 с.

Михлин Б.Ю. Фибулы Беляусского могильника // СА. 1980. №3. С. 194-213.

Мордвинцева В.И. Полихромный звериный стиль. Симферополь: «Универсум». 2003. 216 с.

Мошеева О.Н. Глазчатые бусы // РА. 2008. №4. С. 23-33.

Мошкова М.Г. О раннесарматских втульчатых стрелах // КСИА. Вып. 89 / Отв. ред. Т.С. Пассек. М.: AH CCCP, 1962. C. $77-82$

Мошкова М.Г. Памятники прохоровской культуры / САИ. Вып. Д1-10. М.: АН СССР. 1963. 56 с., 32 табл.

Мошкова М.Г. Среднесарматские и позднесарматские памятники на территории южного Приуралья // Сарматские культуры Евразии: проблемы региональной хронологии. Доклады к 5 межд. конф. «Проблемы сарматской археологии и истории» / Отв. ред. Б.А. Раев. Краснодар: Фирма НСС, 2004. C. 22-44.

Мошкова М.Г. Максименко В.Е. Сарматские погребения ясыревских курганов нижнего Дона // КСИА. Вып. 133. М.: Наука, 1973. С. 72-79.

Мошкова М.Г., Федорова -Давыдова Э.А. Работы Цимлянской экспедиции 1970 г. // Археологические памятники Нижнего Подонья. Ч.І / Отв. ред. М.Г. Мошкова, Д.Б. Шелов. М.: Наука-ВЛ, 1974. C. 21-121.

Мыськов Е.П., Кияшко А.В., Скрипкин А.С. Погребение сарматской знати с Есауловского Аксая // НАВ. Вып. 2. / Отв. ред. А.С. Скрипкин, Волгоград: ВолГУ, 1999. С. 149-167.

Никитина Г.Ф. Могильник у с.Оселивка Кельменецкого района Черновицкой обл. // Могильники черняховской культуры. Вып. 2. / Отв. ред. В.В. Кропоткин. М.: Наука, 1988. С. 5-97.

Никитина Г.Ф. Черняховская культура Поднестровья (по результатам анализа археологических источников). М.: Таус, 2008. 448 с.

ОАК за 1895 г. СПб: Типография главного управления уделов, 1897. $201 \mathrm{c.}$

Петренко B.A. Хронология сарматского погребального инвентаря Среднего Притеречья (III в. до н.э. - IV в. н.э.) // Проблемы хронологии сарматской культуры / Отв. ред. А.С. Скрипкин. Саратов: Саратовский университет, 1992. С. 32-45.

Плетнева С.А. От кочевий к городам. Салтово-маяцкая культура / МИА. № 142. М.: Наука, 1967. $198 \mathrm{c}$.

Плетнёва С.A. На славяно-хазарском пограничье. Дмитриевский археологический комплекс. М.: Наука, 1989. 288 с.

Пуздровский А.Е. Крымская Скифия II в. до н.э. - III в. н.э. Погребальные памятники. Симферополь: Бизнес-Информ, 2007. 480 с. 
Пуздровский А.Е. Ритуальные предметы из погребений «жриц» Усть-Альминского некрополя // Боспорский феномен: сакральный смысл региона, памятников, находок. Ч.2 / Отв. ред. В.Ю. Зуев. СПб.: ГЭ, 2007. С. 278-285.

Пуздровский A.E. Комплекс с бронзовой и серебряной посудой I в. н.э. из Усть-Альминского некрополя в Крыму // Stratum plus. 2005-2009. №4. С. 329-338.

Пуздровский А.Е., Труфанов А.А. Полевые исследования Усть-Альминского некрополя в 2000-2003 гг. Симферополь, М.: Типография ИП Зуева Т.В., 2017а. 298 с.

Пуздровский А.Е., Труфанов А.А. Полевые исследования Усть-Альминского некрополя в 2004-2007 гг. Симферополь: ИП Бровко, 2017б. 372 с.

Пуздровский А.Е., Труфанов А.А., Юрочкин В.Ю. Охранные работы в Бахчисарайском р-не // АИК. 1995 г. / Отв. ред. В.Л. Мыц. Симферополь: Сонат, 2007. С. 117-125..

Раев Б.А. Бронзовая посуда эпохи позднего латена в Сарматии // Античный мир и археология. 1993. № 9. C. $160-175$.

Раев Б.А. О новых датировках и старых проблемах, спорных моментах, и бесспорных истинах // Раннесарматская и среднесарматская культуры. Проблемы соотношения: материалы семинара Центра изучения истории и культуры сарматов. Вып. 1 / Отв. ред. В.М. Клепиков. Волгоград: ВолГУ, 2006. С. 91-100.

Рыюжова Л.А. Бронзовые ажурные подвески из раскопок в ю-з Крыму // Херсонесский сборник. 2005. Вып. XIV. C. 283-290.

Саттаров P.P. К вопросу о применении импортных бронзовых наконечников стрел населением пьяноборской культуры // Этносы и культуры Урало-Поволжья: история и современность: мат-лы ХІ Всероссийской научно-практической конф. молодых ученых / Отв. ред. Э.В. Камалеев. Уфа: ИЭИ УНЦ PAH, 2017. C. 103-106.

Саттаров Р.Р. Импортные предметы в пьяноборской культуре (конец II в. до н.э. - II в. н.э.). Дисс. ... канд. ист. наук. Казань, 2019. 167 с.

Сергаџков И.В. Проблема формирования среднесарматской культуры // Археология Волго-Уральского региона в эпоху раннего железного века и средневековья / Отв. за Вып. А.С. Скрипкин. Волгоград: ВолГУ, 1999. С. 137-155.

Сергаиков И.В. Сарматские курганы на Иловле. Волгоград: ВолГУ, 2000. 396 с.

Сергацков И.В. О конечной дате раннесарматской культуры // НАВ. Вып. 3. / Отв. ред. А.С. Скрипкин. Волгоград: ВолГУ, 2000б. С. 113-122.

Сергачкков И.В. К хронологии среднесарматской культуры нижнего Поволжья // Сарматские культуры Евразии: проблемы региональной хронологии. Доклады к 5 межд. конф. «Проблемы сарматской археологии и истории» / Отв. ред. Б.А. Раев. Краснодар: Фирма НСС, 2004. С. 107-116.

Сергаиков И.В., Дворниченко В.В., Демкин В.А. Курганный могильник Маляевка V // Материалы по археологии Волго-Донских степей. Вып. 1 / Отв. ред. И.В. Сергацков. Волгоград: ВолГУ, 2001. C. $13-63$.

Сергаџков И.В., Захаров П.Е. Сарматское погребение на севере Волгоградской области // РА. 2006. №1 C. $117-123$.

Симоненко А.В. Погребение у с.Чистенькое и «странные комплексы» последних вВ. до н.э. // НАВ. Вып. 4. / Отв. ред. А.С. Скрипкин. Волгоград: ВолГУ, 2001. С. 92-106.

Симоненко A.B. Вместо заключительного слова // Раннесарматская и среднесарматская культуры. Проблемы соотношения: материалы семинара Центра изучения истории и культуры сарматов. Вып. 1 / Отв. ред. В.М. Клепиков. Волгоград: ВолГУ, 2006а. С. 101-117.

Симоненко A.B. Стекло миллефиори в сарматских погребениях // Liber Archaeologicae: сборник статей, посвящ. 60-летию Б.А. Раева / Ред. А.В. Симоненко. Краснодар, 2006б. С. 137-152.

Симоненко А.В. Сарматские всадники Северного Причерноморья. Saint Petersburg: Нестор-История, $2010.328 \mathrm{c}$.

Симоненко A.B. Римский импорт у сарматов Северного Причерноморья. СПб.: Филологический факультет СПбГУ, 2011. 272 с.

Синиџын И.В. Археологические исследования Заволжского отряда (1951-1953 гг.) // Древности Нижнего Поволжья. (Итоги работ Сталинградской археологической экспедиции). T.I / МИА. №60 / Отв. ред. Е.И. Крупнов. М.: АН СССР, 1959. С. 39-205.

Синищын И.В. Древние памятники в низовьях Еруслана (по раскопкам 1954-1955 гг.) // Древности нижнего Поволжья. Т.ІІ / МИА. №78 / Отв. ред. Е.И. Крупнов, К.Ф. Смирнов. М.: АН СССР, 1960. С. 10-108.

Скалон К.М. О культурных связях Восточного Прикаспия в позднесарматское время // АСГЭ Вып.

2 / Ред. М.И. Артамонов. Л.: ГЭ, 1961. С. 114-140.

Сквориов Н.Б. Материалы раскопок курганного могильника «Западные могилы» // Древности ВолгоДонских степей. Вып. 7 / Сост., научн.ред. В.И. Мамонтов. Волгоград: тип. Аркол, 2017. С. 43-71. 
Скрипкин А.С. Фибулы Нижнего Поволжья (по материалам сарматских погребений) // СА. 1977. №2. C. 100-120.

Скрипкин А.С. Азиатская Сарматия. Проблемы хронологии и ее исторический аспект. Саратов: Саратовский ун-т, 1990.300 с

Скрипкин А.С. К проблеме выделения сарматских памятников азиатской Сарматии II-I вв. до н.э. // Раннесарматская культура: формирование, развитие, хронология. Материалы IV международной конференции «Проблемы сарматской археологии и истории». Вып. 1. / Отв. ред. В.Н. Мышкин. Самара: СНЦ РАН, 2000. С. 137-149.

Скрипкин А.С. Сарматские мечи с кольцевым навершием // II Городцовские чтения. Материалы научной конференции, посвященной 100-летию деятельности В.А. Городцова в ГИМ. Апрель 2003 г. / Тр. ГИМ. Вып. 145 / Отв. ред. И.В. Белоцерковская. М.: ГИМ, 2005. С. 171-184.

Скрипкин А.C. К проблеме соотношения ранне и среднесарматской культур // Раннесарматская и среднесарматская культуры. Проблемы соотношения: материалы семинара Центра изучения истории и культуры сарматов. Вып. 2 / Отв. ред. В.М. Клепиков. Волгоград: ВолГУ, 2006а. С. 5-37.

Скрипкин А.C. Вместо заключительного слова // Раннесарматская и среднесарматская культуры. Проблемы соотношения: материалы семинара Центра изучения истории и культуры сарматов. Вып. 2 / Отв. ред. В.М. Клепиков. Волгоград: ВолГУ, 2006б. С. 135-137.

Скрипкин А.С., Мыськов Е.П. Погребения сарматской знати из волгоградского Подонья // АО 1991-2004 гг.: Европейская Россия / Отв. ред. Н.А. Макарова. М.: ИА РАН, 2009. С. 245-255.

Смирнов К.Ф. Сарматские племена Северного Прикаспия // КСИИМК. Вып. XXXIV. М.; Л.: АН CCCP, 1950. C. $97-114$.

Смирнов К.Ф. Вопросы изучения сарматских племен и их культуры в советской археологии // Вопросы скифо-сарматской археологии / Под ред. Н.Я. Мерперт. М: АН СССР, 1954. С. 195-219.

Смирнов К.Ф. Вооружение савроматов / МИА. № 101. М.: АН СССР, 1961. 162 с.

Смирнов К.Ф. Сарматы Нижнего Поволжья и междуречья Дона и Волги в IV в. до н.э. - II в. н.э. (историко-археологический очерк) // СА. 1974. №3. С. 33-44

Сорокина Н.П. Стеклянные сосуды из Танаиса // Древности Нижнего Дона / МИА. №127 / Отв. ред. Д.Б. Шелов. М.: Наука, 1965. С. 202-248.

Среднесарматская культура / Статистическая обработка погребальных памятников Азиатской Сарматии. Вып. ІІІ / Отв. ред. М.Г. Мошкова. М.: Вост.лит., 2002. 143 с.

Степи европейской части СССР в скифо-сарматское время / Отв. ред. А.И. Мелюкова. М.: Наука, 1989. $464 \mathrm{c}$.

Стоянова А.А. Бусы и подвески из могильника Нейзац (по материалам раскопок 1996-2001 гг.) // Боспорские исследования. Вып. V / Ред.-сост. В.Н. Зинько. Симферополь; Керчь: Б.и, 2004. С. 263-320. Стоянова А.А. Металлические подвески в форме топориков из Крыма // Археологія. 2005. №2. C. $47-54$.

Стоянова А.А. Намисто і підвіски населення Криму III ст. до н. е. - IV ст. н.е. . Дисс. ... канд.іст.наук. К., 2006д // НА ІА НАНУ. Ф.12. Д.850.

Стоянова А.А. Детские погребения из могильника Опушки (по результатам раскопок 2003-2009 гг.). Симферополь: Доля, 2012. 100 с.

Стоянова A.A. Об одном типе сарматских бронзовых зеркал из Крыма // Крым в сарматскую эпоху. Вып. V. Мат-лы X Международн. научн. конф. «Проблемы сарматской археологии и истории» / Отв. ред. И.Н. Храпунов. Симферополь: ООО «Фирма «Салта» ЛТД», 2019. С. 253-266.

Сымонович Э.А. Население столицы позднескифского царства (по материалам Восточного могильника Неаполя скифского). К.: Наукова думка, 1983. 172 с.

Тощев Г.Н., Сапожников И.В. Курганная группа у станции Фрикацей // Древности степного Причерноморья и Крыма. Вып. 1. / Под ред. Г.Н. Тощева, Г.И. Шахрова, Г.И. Шаповалова. Запорожье, 1990. C. $13-30$.

Трейстер М.Ю. Оружие сарматского типа на Боспоре (об одной группе кинжалов, изображённых на пантикапейских надгробиях I-II в. н.э.) // Боспор и Северное Причерноморье в античную эпоху. Мат-лы юбилейного междунар. круглого стола, посв. 10-летию конф. «Боспорский феномен» / Отв. ред. В.Ю. Зуев. СПб.: «Нестор-История», 2008. С. 146-160.

Трейстер М.Ю. Оружие сарматского типа на Боспоре в I-II вв. н.э. // Древности Боспора / Гл.ред. А.А. Масленников. Т. 14. М.: ИА РАН, 2010. С. 484-561.

Трейстер М.Ю. Золотые погребальные венки Боспора IV в. до н.э. - V в. н. э. (генезис и хронология основных типов) // Погребальная культура Боспорского царства. Материалы Круглого стола, посвящённого 100-летию со дня рождения Михаила Моисеевича Кубланова / Отв. Ред. В.Ю. Зуев, В.А. Хршановский. СПб.: Нестор-История, 2014 . С. 54-65.

Трейстер М.Ю. Blechkanne. Медные кованые кувшины первых веков н.э. в Северном Причерноморье и Сарматии // Древности Боспора / Гл.ред. А.А. Масленников. Т. 22. М.: ИА РАН, 2018а. С. 216-238. 
Трейстер М.Ю. Парфянские и раннесасанидские «импорты» в погребениях кочевников Восточной Европы (II в. до н.э. - ІІІ в. н.э.) // МАИАСК. Вып. 10. 2018б. С. 118-210.

Трейстер М.Ю. Римские стеклянные сосуды сер. I - сер. ІІІ вв. н.э. из сарматских погребений ВолгоТонского междуречья, нижнего Поволжья и южного Урала // Проблемы истории, филологии, культуры (ПИФК). 2019а. №1. С. 25-68.

Трейстер М.Ю. Таз(-ы) из кургана №1 могильника Октябрьский-V (к вопросу о времени и историческом контексте формирования центра погребальных памятников кочевой элиты в междуречье Дона и Волги) // ВДИ. 2019б. №2. С. 379-415.

Трейстер М.Ю. Литые в формах стеклянные скифосы из погребений кочевни-ков Волго-Донского междуречья и участие сарматов в иберо-парфянской войне 35 г. н.э. // Крым в сарматскую эпоху. Вып. V. Мат-лы X Международн. научн. конф. «Проблемы сарматской археологии и истории» / Отв. ред. И.Н. Храпунов. Симферополь: ООО «Фирма «Салта» ЛТД», 2019в. С. 272-281.

Трейстер М.Ю. Боспорские(?) пряжки из драгоценных металлов I в. н.э. на Боспоре и в Сарматии // Древности Боспора / Гл.ред. А.А. Масленников. Т. 25 М.: ИА РАН, 2020а. С. 384-406.

Трейстер М.Ю. Римские бронзовые ковши из погребений кочевников Азиатской Сарматии // Проблемы истории, филологии, культуры (ПИФК). 2020б. №2. С. 5-60.

Трейстер М.Ю. Римские бронзовые тазы Eggers 99-106 в Восточной Европе // Проблемы истории, филологии, культуры (ПИФК). 2020в. №3. С. 5-48.

Трейстер М.Ю. Бронзовые сосуды позднереспубликанского времени из погребений кочевников Азиатской Сарматии // Проблемы истории, филологии, культуры (ПИФК). 2020г. №4. С. 41-109.

Троицкая T.H. Находки из скифских курганов Крыма, хранящиеся в областном краеведческом музее

// История и археология Древнего Крыма / Отв. ред. П.Н. Шульц. Киев: АН УССР. 1957. С. 174-190.

Труфанов А.А. Подбойные могилы III в. н.э. из некрополя у с.Курское (по материалам раскопок 2001

г.) // Сугдейский сборник / Отв. за Вып. Н.М. Куковальская. Киев, Судак: «ТОВ Горобецъ», 2003/2004.. C. $495-521$.

Труфанов А.A. Пряжки ранних провинциально-римских форм в Северном Причерноморье // РА. 2004a. №3. С. 160-170.

Труфанов А.А. Дополнения к опубликованным материалам гробниц в «Тавельских» курганах 1897 г. // У Понта Эвксинского (памяти П.Н. Шульца) / Ред.-сост. С.Г. Колтухов. Симферополь: КрымНЦ ИА НАНУ, 20046. С. 135-138.

Труфанов А.А. Зеркала-подвески первых веков н.э. из могильников Крымской Скифии // Древняя Таврика. Посвящ. 80-летию Т.Н. Высотской / Общ.ред. Ю.П. Зайцев, В.И. Мордвинцева. Симферополь: Универсум, 2007. С. 173-186.

Труфанов А.А. К вопросу о хронологии браслетов с зооморфными окончаниями (поматериалам крымских могильников позднескифского времени) // Поздние скифы Крыма / Труды ГИМ. Вып. 118. / Отв. ред. И.И. Гущина, Д.В. Журавлёв. М: ИПК «Желдориздат», 2001. С. 71-77.

Труфанов А.А. Хронология могильников Предгорного Крыма I в. до н.э. - III в. н.э. // Stratum plus. 2005-2009. №4. С. 117-328.

Труфанов А.A. Металлические амулеты-подвески Северного Причерноморья первых вв. н.э. // Stratum plus. 2011. №4. C. 223-270.

Труфанов А.А., Мордвинщева В.И. Воинское погребение середины I в. н.э. из Усть-Альминского некрополя (Юго-Западный Крым) // Проблемы истории, филологии, культуры (ПИФК). 2016. №2. С. $196-212$.

Федоров-Давыдов Г.А. Статистическая обработка погребальных памятников Азиатской Сарматии.

Вып. 1. Савроматская эпохи. Отв. редактор М.Г. Мошкова. М., 1994 // РА. 1996. №1. С. 215-221.

Хабдулина М.К. Степное Приишимье в эпоху раннего железа. Алматы: Ракурс, 1994. 170 с.

Хазанов А.М., Черненко С.В. Час і мотиви пограбування скіфських курганів // Археологія. 1979. Вып. 30. С. 18-26.

Хомякова O.A. Гл.5. Браслеты Брянского клада // Брянский клад украшений с выемчатой эмалью восточноевропейского стиля (III в. н.э.) / РСМ. Вып. 18 . Отв. ред. А.М. Обломский. М.-Вологда: ИА РАН - Древности Севера, 2018. С. 86-94, рис.69-79.

Храпунов И.Н. Могильник Дружное (III-IV вв. нашей эры). Lublin: Wydaw. Uniw. M. CurieSkłodowskiej, 2002. 313 c.

Храпунов И.Н. Погребения детей в могильнике Нейзац // Материалы по археологии, истории и этнографии Таврии (МАИЭТ). Вып. ХІІ. Ч. 1. 2006. С. 161-250.

Шабанов С.Б. Сармато-германские контакты в предгорном Крыму в позднеримское время (по материалам стеклянной посуды) // Проблемы истории, филологии, культуры (ПИФК). 2015. №3. С. 213-230

Шаров О.В. Боспор. Полихромные стили позднеримской эпохи // НАВ. 2019. Т.18. №2. С. 197-220.

Шевченко Н.Ф. Стрелы у сарматских племен Прикубанья // Древности Кубани и Черноморья. Кн. 1.

/ Под ред. Б. А. Раева. Краснодар: Скифская галерея, 1993. С. 38-198. 
Шевченко Н.Ф. «Сарматские жрицы», или еще раз к вопросу о материнском роде у сарматов // ВДИ. 2006. №1. С. 141-154.

Шевченко О.Б. Захисні амулети з наконечників стріл у жиночіх похованнях сарматів // Античный Никоний и мир племен Северо-Западного Причерноморья. Материалы «круглого стола», посвящ. юбилею Н.М. Секерской и 60-летию начала раскопок Никония (Одесса, 18 мая 2017 г.) / Отв. ред. И.В. Бруяко, А.В. Главенчук. Одесса, 2018. С. 77-85.

Шелов Д.Б. Узкогорлые светлоглиняные амфоры первых веков нашей эры. Классификация и хронология // КСИА. Вып. 156. М.: Наука, 1978. С. 16-22.

Шинкарь O.A. Золотоордынский клад из с. Василицы Черкасской области // Город и степь в контактной Евро-Азиатской зоне. Тезисы докладов III Международной научной конференции, посвященной 75-летию со дня рождения Г.А. Федорова-Давыдова (1931-2000) / Отв. ред. В.В. Мурашева. М.: Нумизматическая лит-ра, 2006. С. 57-59.

Шинкарь O.A. Типология и хронология раннесарматских наконечников стрел по материалам Нижнего Поволжья // Вопросы истории и археологии Западного Казахстана. 2007. №1. С. $103-119$.

Юрочкин В.Ю., Труфанов А.А. Позднеантичный погребальный комплекс в низовьях р.Качи // Херсонесский сборник. Вып. ХІІ. / Отв. ред. М.И. Золотарев. Симферополь, 2003. С. 199-128.

Яблонский Л.Т., Дэвис-Кимболл Дж., Демиденко Ю.В. Раскопки курганных могильников Покровка 1 и Покровка 2 в 1994 г. // Курганы левобережного Илека. Вып. 3 / Отв. ред. Л.Т. Яблонский. М.: ИА РAH, 1995. С. 9-47, 100-175.

Яиееко С.А. Орудия ранних эпох в погребальных и жилых комплексах античных городов северного Причерноморья и окружающих варварских племен // Боспорский феномен: сакральный смысл региона, памятников, находок. Ч.2 / Отв. ред. В.Ю. Зуев. СПб.: ГЭ, 2007. С. 275-279.

Feugère M. Les Fibules en Gaule Méridionale (de la conquête à la fin du V s. ap. J.-C.) / Revue Archéologique de Narbonnaise. Suppl. 12. Paris: Centre National de la Recherche Scientifique, 1985. 503 p.

Istvánovits E., Kulcsár V. Sarmatian archery in the Carpathian Basin - revisited // Honoratissimum assensus genus est armis laudare / red. R. Madyda-Legutko-J. Rodzieńska-Nowak. Kraków, 2014. P. $143-149$.

Marčenko I.I., Limberis N.Ju. Römische Importe in sarmatischen und maiotischen Denkmälern des Kubangebietes // Simonenko A., Marčenko I.I., Limberis N.Ju. Römische Importe in sarmatischen und maiotischen Gräbern / Archäologie in Eurasien. B.25. Mainz: Ph. von Zabern, 2008. S. 265-402, Taf. 1-222.

Raev B. Roman Imports in the Lower Don Basin / BAR International series 278. Oxford: BAR., 1986. $135 \mathrm{p}$.

Riha E. Die Römischen Fibeln aus Augst und Kaiseraugst / Forschungen in Augst. Bd.3. Augst, 1979. $201 \mathrm{~S}$

Simonenko A.V. Römische Importe in sarmatischen Denkmälern des nördlichen Schwarzmeergebietes // Simonenko A., Marčenko I.I., Limberis N.Ju. Römische Importe in sarmatischen und maiotischen Gräbern / Archäologie in Eurasien. B.25. Mainz: Ph. von Zabern, 2008. S. 1-95, Taf. 1-168.

Treister M. Gold vessels, perfume flasks and pyxides from Sarmatia // Pontus and the outside wordl. Studies in Black Sea History, Historiography and Archaeology / Colloquia Pontica. Vol.9 / Ed. Chr.Tuplin. Leiden; Boston, 2004. P. 131-193.

\section{Информация об авторе:}

Красноперов Александр Анатольевич, кандидат исторических наук, научный сотрудник ,Удмуртский институт истории, языка и литературы УдмФИЦ УрО РАН (г. Ижевск, Россия); khaa@udm.ru

\section{REFERENCES}

Abramova, M. P. 1951. In Sovetskaya arkheologiya (Soviet archeology). (1). 52-71 (in Russian). Abramova, M. P. 1969. In Evtyukhova, L. A. (ed.). Materialy i issledovaniia po arkheologii SSSR (Materials and Research in Archaeology USSR) 155. Moscow: "Nauka" Publ., 3-10 (in Russian).

Abramova, M. P. 1983. In Kratkie soobshcheniia Instituta arkheologii (Brief Communications of the Institute of Archaeology) 176. Moscow: "Nauka" Publ., 34-40 (in Russian).

Abramova, M. P. 1993. Tsentral'noe Predkavkaz'e v sarmatskoe vremia (III v. do n.e. - IV v. n.e.) (Central Ciscaucasus in Sarmatian Time (3 ${ }^{\text {rd }}$ Century BC $-4^{\text {th }}$ Century AD)). Series: Afanas'ev, G. E., Daim, F. with J. Kidd's contribution (series Chief Editors). Arkheologiia epokhi velikogo pereseleniia narodov i rannego srednevekov'ia = Russian monographs in migration-period and medieval archaeology 2. Moscow: Institute of Archaeology, Russian Academy of Sciences (in Russian).

Alekseeva, E. M. 1978. Antichnye busy Severnogo Prichernomor'ia (Ancient Beads of Northern Pontic Region). Series: Svod Arkheologicheskikh Istochnikov (Corpus of Archaeological Sources) GI-12. Moscow: "Nauka" Publ. (in Russian).

Alekseeva, E. M. 1982. Antichnye busy Severnogo Prichernomor'ia (Ancient Beads of North Pontic). Series: Svod Arkheologicheskikh Istochnikov (Corpus of Archaeological Sources) GI-12. Moscow: "Nauka" Publ. (in Russian). 
Arsen'eva, T. M. 1970. In Melyukova, A. I. (ed.). Materialy i issledovaniia po arkheologii SSSR (Materials and Research in Archaeology USSR) 155. Moscow: Academy of Sciences of the USSR, 82-149 (in Russian).

Babenchikov, V. P. 1957. In Shults, P. N. (ed.). Istoriia $i$ arkheologiia Drevnego Kryma (History and Archaeology of Ancient Crimea). Kiev: Academy of Sciences of the Ukrainian SSR Publ., 94-141. (in Russian).

Balahvantsev, A. S. 2020. In Gadzhiev, M. S. (ed.). Arkheologicheskoe nasledie Kavkaza: aktual'nye problemy izucheniia i sokhraneniia. XXXI "Krupnovskie chteniia" (Archaeological Heritage of the Caucasus: Topical Issues of Study and Preservation. (XXXI Krupnov Readings on the Archaeology of the North Caucasus). Mahachkala, 184-186. (in Russian).

Bezuglov, S. I. 2000. In Guguev, Yu. K. (ed.). Sarmaty i ikh sosedi na Donu (Sarmatians and Their Neighbors on the Don). Series: Materialy i issledovaniia po arkheologii Dona (Materials and Research of the Don Archaeology) I. Rostov-on-Don: "Terra" Publ., 169-193 (in Russian).

Bezuglov, S. I. 2001. In Donskaia arkheologiia (Archaeology of Don) (1-2), 57-61 (in Russian).

Bezuglov, S. I. 2017. In Il'yashenko, S. M. (ed.). Vestnik Tanaisa (Herald of Tanais.). (4). Nedvigovka Myasnikovsky district of Rostov region: Archaeological museum-reserve "Tanais" Publ. 84-147 (in Russian).

Bezuglov, S. I., Glebov, V. P., Parusimov, I. N. 2009. Pozdnesarmatskie pogrebeniya v ust'e Dona (kurgannyj mogil'nik Valovyj I) (Late Sarmatian Burials at the Mouth of the Don (Valovy I Burial Mound)). Rostov On Don: "Media-Polis" Publ. (in Russian).

Vadai, A. Kh., Kul'char V. 1984. In Acta Archaeologica Academiae Scientiarum Hungaricae. Vol. 36, 239-261. (in Russian).

Vinogradov, V. B., Petrenko, V.A. 1974. In Sovetskaya arkheologiya (Soviet archeology). (1). 171-180 (in Russian).

Vlaskin, V. M. 1990. In Maksimenko, V. E. (ed.). Istoriko-arkheologicheskie issledovaniia v Azove i na Nizhnem Donu (Historical and Archaeological Research in Azov and Lower Don Region) 9. Azov: Azov Historical-Archaeological and Palaeontological Museum-Reserve, 64-68 (in Russian).

Vysotskaya, T. N. 1994. Ust'-Al'minskoe gorodishche i nekropol' (Ust-Alma Hillfort and Necropolis). Kiev:

"Kiev. Akad. Evrobiznesa" Publ. (in Russian).

Glebov, V. P. 2007a. In Yablonsky, L. T., Tairov, A. D. (eds.). Vooruzhenie sarmatov: regional'naia tipologiia i khronologiia (Armament of Sarmatians: Regional Typology and Chronology). Chelyabinsk: South Ural State University, 88-98 (in Russian).

Glebov, V. P. 2007b In Sergatskov, I. V. (ed.). Regional'nye osobennosti rannesarmatskoi kul'tury (Regional Features of Early Sarmatian Culture). 2. Volgograd: Volgograd State University, 59-82. (in Russian).

Glebov, V. P. 2017 In Skhatum, R. B. (ed.). VII "Anfimoskie chteniia” po arkheologii zapadnogo Kavkaza (7th "Anfimov Readings" on the Archaeology of the Western Caucasus). Krasnodar: "IP Smorodin" Publ., 53-62. (in Russian).

Glebov, V. P. 2019 In Nizhnevolzhskii arkheologicheskii vestnik (Lower Volga Archaeological Bulletin) 18 (2), 86-104 (in Russian).

Glebov, V. P., Il'yashenko. S. M., Tolochko, I. V. 2004. In Zuev, V. Yu. (ed.). Bosporskii fenomen: problem khronologii $i$ datirovki pamiatnikov (The Bosporan Phenomenon: Issues of Chronology and Dating of Monuments). 1. Saint Petersburg: The State Hermitage Museum, 292-307 (in Russian).

Glebov, V. P., Tolochko, I. V. 2016. In Luk'yashko, S. I. (ed.). Antichnaia tsivilizatsiia i varvarskii mir Ponto-Kaspiiskogo regiona (Ancient Civilization and the Barbarian World of the Pontic-Caspian Region). Rostov On Don: Southern Scientific Center of Russian Academy of Sciences, 44-84 (in Russian).

Glukhov, A. A. 2005. Sarmaty mezhdurech'ia Volgi i Dona v I-pervoi polovine II v. n.e. (Sarmatians in the Volga and Don Interfluves Area in $1^{\text {st }}-$ First Half of $2^{\text {nd }} c$. AD). Volgograd: "Volgogradskoe nauchnoe izdatelstvo" Publ. (in Russian).

Gmyrya, L. B. 2011. In Vestnik Instituta istorii, arkheologii i etnografii (Herald of the Institute of History, Archaeology and Ethnography). 4, 36-80 (in Russian).

Gorbenko, A. A., Kosyanenko, V. M. 2011. Nekropol' Paniardisa (Krepostnogo gorodishcha) (Necropolis of Paniardis (Fortress Settlement)). Series: Donskie drevnosti (Antiquities of the Don). 11. Azov: Azov Museum of Local Lore (in Russian).

Grach, N. L. 1999. Nekropol' Nimfeya (Nimpheus necropolis). Saint Petersburg: "Nauka” Publ. (in Russian). Grishakov, V. V., Zubov, S. E. 2009. Andreevskii kurgan v sisteme arkheologicheskikh kul'tur rannego zheleznogo veka Vostochnoi Evropy (Andreevka Burial Mound in the System of the Early Iron Age Archaeological Cultures of Eastern Europe). Series: Arkheologiia evraziiskikh stepei (Archaeology of the Eurasian Steppes) 7. Kazan: Institute of History named after Shigabuddin Mardzhani, Tatarstan Academy of Sciences; Samara Municipal Institute for Public Administration (in Russian).

Guguev, V. K., Bezuglov, S. I. 1990. In Sovetskaya arkheologiya (Soviet archeology). (2). 164-175 (in Russian).

Gushchina, I. I., Zasetskaya, I. P. 1989. In Abramova, M. P. (ed.). Arkheologicheskie issledovaniia na iuge Vostochnoi Evropy (Archaeological Studies in the South of Eastern Europe). Series: Proceedings of the State Historical Museum 70. Moscow: "Nauka" Publ., 71-141 (in Russian). 
Gushchina, I. I., Zasetskaya, I. P. 1994. "Zolotoe kladbishhe» Rimskoy epokhi v Prikuban'e ("Golden cemetery" of the Roman Age in the Kuban' basine). Series: Russian Archaeological Library. Issue 1. Saint Petersburg: "Farn" Publ. (in Russian).

Dashevskaia, O. D. 1991. Pozdnie skify v Krymu (Late Scythians in the Crimea). Svod Arkheologicheskikh Istochnikov (Corpus of Archaeological Sources) D1-7. Moscow: "Nauka" Publ. (in Russian).

Dashevskaya, O. D. 2013. In Rossiiskaia Arkheologiia (Russian Archaeology) (1), 160-163 (in Russian).

Dashevskaya, O. D. 2014. Nekropol' Belyausa (Belyaus Necropolis). Simferopol: "Feniks" Publ. (in Russian).

Dvornichenko, V. V., Malinovskaya, N. V., Fedorov-Davydov, G. A. 1977 In Fedorov-Davydov, G. A. (ed.) Drevnosti Astrahanskogo kraia (Antiquities of the Astrakhan Region). 4. Moscow: "Nauka" Publ., 3-78, 83-194 (in Russian).

Dvornichenko, V. V., Fedorov-Davydov, G. A., Bulatov, N. M. 1989. In Smirnov, A. K. (ed.). Sokrovishcha sarmatskikh vozhdei $i$ drevnie goroda Povolzh'ia (Treasures of Sarmatian leaders and ancient towns of the Volga region). Moscow: "Nauka" Publ., 14-132 (in Russian).

Demidenko, S. V. 2007. In Rossiiskaia Arkheologiia (Russian Archaeology) (2), 48-54 (in Russian).

Demidenko, S. V. 2008. Bronzovye kotly drevnikh plemen Nizhnego Povolzh'ia i Iuzhnogo Priural'ia (V $v$ do n.e. - III v. n.e.) (Bronze Cauldrons of Antient Tribes from the Lower Volga and the Southern Urals (5th Century B.C. $-3^{\text {rd }}$ Century A.D.)). Moscow: "URSS" (in Russian).

Demidenko, S. V. 2014. In Ongar, A. (ed.). Vsadniki Velikoi stepi: traditsii i novatsii (Riders of the Great Steppe: Traditions and Innovations.). Series: Trudy filiala Instituta arkheologii im. A. Kh. Margulana v g. Astana (Proceedings of the Branch of the A. Kh. Margulan Institute of Archaeology in Astana) IV. Astana: The Branch of the Institute of Archaeology in Astana, 8-21 (in Russian).

Didenko, S. V. 2014. In Petrauskas, O. V., Gorbanenko, S. A. (eds.). Cherniahivs'ka kul'tura (Chernyakhiv Culture). Series: OIUM. 4. Kiev: Institute of Archaeology of the National Academy of Sciences of Ukraine, 34-48 (in Russian).

D'yachenko, A. N., Zhelezchikov, B. F. 1995. In Luk'iashko, S. I. (ed.). Donskie drevnosti (Antiquities of the Don). 4. Azov: Azov Museum of Local Lore, 149-168 (in Russian).

Zhdanovskii, A. M. 1984. In Kirei, N. I. (ed.). Arkheologo-etnograficheskie issledovaniia Severnogo Kavkaza (Archaeological and Ethnographical Research in the Northern Caucasus). Krasnodar: Kuban State University, $72-99$ (in Russian).

Zhdanovskii, A. M. 1988. In Vinogradov, V. B. (ed.). Problemy arkheologii i etnografii Severnogo Kavkaza (Issues of Archaeology and Ethnography of the North Caucasus). Krasnodar: Krasnodar State University, 54-68 (in Russian).

Zaitsev, Yu. P. 1993. In Vestnik drevnei istorii (Journal of Ancient History) (3). 127-148 (in Russian).

Zaitsev, Yu. P. 2004. In Zakharova, N. A. (comp.). Iuvelirnoe iskusstvo i material'naia kul'tura (Jewellery Art and Material Culture). Saint Petersburg: The State Hermitage Museum, 47-50 (in Russian).

Zaitsev, Yu. P., Mordvitseva, V. I. 2003. In Rossiiskaia Arkheologiia (Russian Archaeology) (2), 135-154

(in Russian).

Zasetskaya, I. P. 2004. In Soobshcheniia Gosudarstvennogo Ermitazha (Reports of the State Hermitage Museum) 62. Saint Petersburg: The State Hermitage Publ. 54-61 (in Russian).

Zasetskaya, I. P. 2011. Sokrovishcha kurgana Khohlach. Novocherkasskii klad (Treasures of the Khokhlach Burial Mound. Novocherkassk Hoard). Saint Petersburg: The State Hermitage Publ. (in Russian).

Zasetskaya, I. P. 2019. Iskusstvo zverinogo stilia sarmatskoi epokhi (II v. do n.e. - nachalo II v. n.e.) (The Art of the Animal Style of the Sarmatian Era (II Century BC - early II Century AD)). Simferopol: "Antikva" Publ. (in Russian).

Zasetskaya, I. P., Il'yukov, L. S., Kosyanenko, V. M. 1999. In Donskaia arkheologiia (Archaeology of Don) (2), 51-60 (in Russian).

Zasetskaya, I. P., Marchenko, I. I. 1995. In Shchukin, M. B. (ed.). Arkheologicheskii sbornik Gosudarstvennogo Ermitazha (Archaeological Bulletin of the State Hermitage Museum) 32. Saint Petersburg: State Hermitage Museum, 90-104 (in Russian).

Zakharov, A. V. 2000. In Guguev, Yu. K. (ed.). Sarmaty $i$ ikh sosedi na Donu (Sarmatians and Their Neighbors on the Don). Series: Materialy i issledovaniia po arkheologii Dona (Materials and Research of the Don Archaeology) I. Rostov-on-Don: "Terra" Publ., 27-45 (in Russian).

Zubov, S. E. 2007. In Kiyashko, A. V., Skripkin, A. S. (eds.). Problemy arkheologii Nizhnego Polozh'ia (Issue of the Archaeology of the Lower Volga Region) Volgograd: Volgograd State University, 87-96 (in Russian).

Zubov, S. E., Sattarov, R. R. 2018. In Vybornov, A. A. (ed.). XXI Ural'skoe arkheologicheskoe soveshchanie (2 $1^{\text {th }}$ Urals Archaeological Congress)). Samara: "Samara State University of Social Sciences and Education", "Porto-Print" Publ., 210-214 (in Russian).

Zuev, V. Yu. 1997. K voprosu o "savromatskoi» kul'ture (On the Issue of the "Savromatians" Culture). Saint Petersburg: State Hermitage (in Russian). 
Zuev, V. Yu. 1998. Rannesarmatskaia kul'tura IV-III vv. do n.e. Statisticheskii fenomen i arkheologicheskaia real'nost' (Early Sarmatian Culture of the $4^{\text {th }}-3^{\text {rd }}$ Centuries BC. Statistical Phenomenon and Archaeological Reality) 2. Saint Petersburg. (in Russian).

Zuev, V. Yu. 1999. In Stratum plus. Archaeology and Cultural Anthropology (3), 305-324 (in Russian).

Zuev, V. Yu. 2000. In Myshkin, V. N. (ed.). Rannesarmatskaia kul'tura: formirovanie, razvitie, khronologiia (Early Sarmatian Culture: Formation, Development, Chronology) Samara: Institute of Archaeology, Russian Academy of Sciences, 85-104. (in Russian).

Zuev, V. Yu. 2004. In Raev, B. A. (ed.). Sarmatskie kul'tury Evrazii: problemy regional'noi khronologii (Sarmatian Cultures of Eurasia: Issues of Regional Chronology). Krasnodar: Kuban State University, 205-220. (in Russian).

Zuev, V. Yu. 2012. In Krivenko, O. A. (ed.). Zoloto, kon' i chelovek (Gold, Horse and Man). Kiev: "Skif" Publ., 385-410 (in Russian).

Il'iukov, L. S., Vlaskin, M. V. 1992. Sarmaty mezhdurech'ya Sala i Manycha (The Sarmatians between the Sal and Manych Rivers). Rostov On Don: Rostov State University (in Russian).

Ishtvanovich, E., Kul'char, V. 2017. In Skiba, A. V., Gorbanenko, S. A. (eds). Evropeis'ka arkheologiia I tys. n.e. (European Archaeology of the First Millennium AD). Kiev, 51-62. (in Russian).

Klepikov, V. M. 2002. Sarmaty Nizhnego Povolzh'ia v IV-III vv. do n.e. (The Sarmatians of the Lower Volga Region in the 4th-3rd Centuries BC). Volgograd: Volgograd State University Publ. (in Russian).

Klepikov, V. M., Skripkin, A. S. 2002. In Skripkin, A. S., Yablonsky, L. T. (eds.). Nizhnevolzhskii arkheologicheskii vestnik (Lower Volga Archaeological Bulletin) 5. Volgograd: Volgograd State University, 47-81 (in Russian).

Kovpanenko, G. T. 1986. Sarmatskoe pogrebenie I veka n.e. na Iuzhnom Buge (Sarmatian Burial of 1st Century A.D. on the Southern Bug). Kiev: "Naukova dumka" Publ. (in Russian).

Koltukhov, S. G., Senatorov, S. N. 2016. Skify Predgornogo Kryma v VII-IV vv. do n.e. Kurgany 1890 1892 i 1895 gg. (po materialam N.I. Veselovskogo i Iu.A. Kulakovskogo) (The Scythians of Piedmont Crimea in $7^{\text {th }}-4^{\text {th }}$ Centuries B.C. Barrows of 1890-1892 and 1895 (on Materials by Veselovsky, N. I. and Kulakovsky, Yu. A.)). In Materialy k arkheologicheskoi karte Kryma (Materials for the Archaeological Map of Crimea) XVII. Simferopol: "IP Brovka A.A." Publ. (in Russian).

Koltukhov, S. G., Toshchev, G. N. 1998. Kurgannye drevnosti Kryma (Barrow Antiquities of Crimea) 2. Zaporozh'e (in Russian).

Korpusova, V. N. 1983. Nekropol' Zolotoe. K etnokul'turnoi istorii evropeiskogo Bospora (Necropolis Zolotoe. On the Ethnocultural History of the European Bosporus). Kiev: "Naukova dumka" Publ. (in Russian).

Kostenko, V. I. 1993. Sarmaty v nizhnem Podneprov'e po materialam Ust'-Kamenskogo mogil'nika (The Sarmatians in the Lower Dnieper Region based on Materials from the Ust-Kamensk Burial Ground). Dnepropetrovsk (in Russian).

Kostromichev, D. A. 2015. In Stratum plus. Archaeology and Cultural Anthropology (4), 299-356 (in Russian).

Kotovich, V. G. 1959. In Daniyalov, G. D. (ed.). Materialy po arkheologii Dagestana (Materials on the Archaeology of Dagestan) 1. Mahachkala: "Dagestanskoe knizhnoe izdatel'stvo" Publ., 121-156 (in Russian). Krasnopeorov, A. A. 2019. In Gavritukhin, I. O., Vorontsov, A. M. (eds.). Lesnaia i lesostepnaia zony Vostochnoi Evropy v epokhi rimskikh vliianii $i$ Velikogo pereseleniia narodov (Forest and Forest-steppe Zone of Eastern Europe during the Era of Roman Influence and the Great Migration) 2. Tula: "Kulikovo Pole" State Museum-Reserve, 103-190 (in Russian).

Krasnopeorov, A. A., Bahshiev, I. I. 2019. In Tomskii zhurnal lingvisticheskikh i antropologicheskikh issledovanii (Tomsk Journal of Linguistics and Anthropology). 25(3), 104-115. (in Russian).

Krivosheev, M. V. 2005d. Pozdnesarmatskaia kul'tura iuzhnoi chasti mezhdurech'ia Volgi i Dona. Problemy khronologii i periodizatsii (Late Sarmatian Culture of the Southern Part of the Volga-Don Interfluve. Issues of Chronology and Periodization). Diss of candidate of historical Sciences. Volgograd (in Russian).

Kropotov, V. V. 2010. Fibuly sarmatskoi epokhi (Fibulae of the Sarmatian Epoch). Kiev: "ADEFUkraina" Publ. (in Russian).

Kunina, N. Z. 1997. Antichnoe steklo v sobranii Ermitazha (Ancient Glass in the Hermitage Collection). Saint Petersburg: "ARS" Publ. (in Russian).

Kurinkikh, O. I. 2011. In Rossiiskaia Arkheologiia (Russian Archaeology) (3), 42-54 (in Russian).

Larenok, V. A. 2013. Meotskie drevnosti. Katalog pogrebal'nyh kompleksov nekropolya Kobyakova gorodishcha iz raskopok 1999-2000 gg. (Meotian Antiquities. Catalog of Burial Complexes of the Kobyakov Fortified Settlement Necropolis from the Excavations of 1999-2000) 1. Rostov on Don: Donskoi Publishing House (in Russian).

Simonenko, A. V. 2006. In Simonenko, A. V. (ed.). Liber Archaeologicae. Krasnodar. 51-77. (in Russian). Limberis, N. Yu., Marchenko, I. I. 2020. In Nizhnevolzhskii arkheologicheskii vestnik (Lower Volga Archaeological Bulletin) 19 (2), 164-182 (in Russian). 
Litvinskii, B. A. 1978. Orudiia truda i utvar' iz mogil'nikov Zapadnoi Fergany (Arkheologicheskie i etnograficheskie materialy po istorii kul'tury i religii Srednei Azii) (Implements and Utensils from Burial Grounds of West Fergana (Archaeological and Ethnographic Materials on the History of Culture and Religion of Central Asia)). Moscow: "Nauka" Publ. (in Russian).

Maksimenko, V. E. 1970. In Sovetskaya arkheologiya (Soviet archeology). (2). 224-232 (in Russian).

Maksimenko, V. E. 1983. Savromaty i sarmaty na Nizhnem Donu (The Sauromats and Sarmatians in the Lower Don). Rostov on Don: Rostov State University (in Russian).

Malashev,V. Yu. 2000. In Guguev, Yu. K. (ed.). Sarmaty i ikh sosedi na Donu (The Sarmatians and Their Neighbors on the Don). Series: Materialy i issledovaniia po arkheologii Dona (Materials and Studies of the Don Archaeology) I. Rostov-on-Don: "Terra" Publ., 194-232 (in Russian).

Malashev, V. Yu. 2013d. Pozdnesarmatskaya kul'tura Yuzhnogo Priural'ya vo II-III vv. n.e. (Late Sarmatian Culture of the Southern Cis-Urals in the $2^{\text {nd }}-3^{\text {rd }} c c$. AD). Diss of candidate of historical Sciences. Moscow (in Russian).

Malashev, V. Yu. 2014. Ufimskii arkheologicheskii vestnik (Ufa Archaeological Herald) (14), 130-140 (in Russian).

Malashev, V. Yu. 2016. Pamiatniki srednesarmatskoi kul'tury severo-kavkazskikh stepei i ikh traditsii v kurgannykh mogil'nikakh Severo-Vostochnogo Kavkaza vtoroi poloviny II - serediny V v. n.e. (Monuments of the Middle Sarmatian Culture of the North Caucasian Steppes and their Traditions in the Burial Mounds of the North-Eastern Caucasus of the Second Half of the $2^{\text {nd }}$ - the Middle of the $5^{\text {th }}$ Century AD). Moscow: Institute of Archaeology, Russian Academy of Sciences (in Russian).

Malyshev, A. A. 2008. In Malyshev, A. A. (ed.). Aspurgiane na yugo-vostoke aziatskogo Bospora: po materialam Tsemdolinskogo nekropolya (The Aspurgians in the South-East of the Asian Bosporus: Based on Materials from Tsemdolinsky Necropolis). Moscow: "Grif i K" Publ., 136-180 (in Russian).

Mamontov, V. I. 1995. In Drevnosti Volgo-Donskikh stepei (Antiquities of Volga-Don Steppes) 5. Volgograd: "Peremena" Publ., 20-33 (in Russian).

Mamontov, V. I. 2000. Drevnee naselenie levoberezh'ya Dona (po materialam kurgannogo mogil'nika Pervomayskiy VII) (Ancient Population of the Left Bank of the Don River (Based on Materials from Pervomaisky VII Burial Mound)). Volgograd: Volgograd State University Publ. (in Russian).

Mamontov, V. I. 2008. In Nizhnevolzhskii arkheologicheskii vestnik (Lower Volga Archaeological Bulletin) 9. Volgograd: Volgograd State University, 170-197 (in Russian).

Marchenko, I. I. 1996. Siraki Kubani (Po materialam kurgannyh pogrebenij Nizhnej Kubani) (The Siraks of Kuban (Based on Materials from Barrow Burials of the Lower Kuban)). Krasnodar (in Russian).

Mayakin, V. V. 2007. In Zaitsev, Yu. P., Mordnitseva, V. I. (eds.). Drevniaia Tavrika. Posviashchsaetsia 80-letiyu T.N. Vysotskoi (Ancient Tavrika. Dedicated to the 80th Anniversary of T.N. Vysotskaya) Simferopol: "Univercum" Publ., 125-138 (in Russian).

Mimokhod R. A., Uspensky P. S. 2019. In Makarov, N. A. (ed.). Novye arkheologicheskie proekty: Vossozdavaia proshloe (New Archaeological Projects: Recreating the Past). Moscow: Institute of Archaeology, Russian Academy of Sciences, 58-61 (in Russian).

Mikheev, V. K. 1985. Podon'e v sostave Khazarskogo kaganata (The Don Region in Khazar Khaganate). Kharkiv (in Russian).

Mikhlin, B. Yu. 1980. In Sovetskaya arkheologiya (Soviet archeology). (3). 194-213 (in Russian).

Mordvintseva, V. I. 2003. Polikhromnyi zverinyi stil'(Polychrome Animal Style). Simferopol: "Universum" Publ. (in Russian).

Mosheeva, O. N. 2008. In Rossiiskaia Arkheologiia (Russian Archaeology) (4), 23 -33 (in Russian).

Moshkova, M. G. 1962. In Passek, T. S. In Kratkie soobshcheniia Instituta arkheologii (Brief Communications of the Institute of Archaeology) 64. Moscow: the USSR Academy of Sciences, 77-82 (in Russian).

Moshkova, M. G. 1963. Pamiatniki prokhorovskoi kul'tury (Monuments of the Prokhorovka culture). Series: Svod Arkheologicheskikh Istochnikov (Corpus of Archaeological Sources) D1-10. Moscow: Academy of Sciences of the USSR (in Russian).

Moshkova, M. G. 2004. In Raev, B. A. (ed.). Sarmatskie kul'tury Evrazii: problemy regional'noi khronologii (Sarmatian Cultures of Eurasia: Issues of Regional Chronology). Krasnodar: Kuban State University, 22-44. (in Russian).

Moshkova, M. G.,Maksimenko, V. E. 1973. In Kratkie soobshcheniia Instituta arkheologii (Brief Communications of the Institute of Archaeology) 133. Moscow: "Nauka" Publ., 72-79 (in Russian).

Moshkova, M. G., Fedorova-Davydova, E. A. 1974. In Moshkova, M. G., Shelov D. B. (eds.). Raboty Tsimlianskoi Ekspeditsii 1970. Arheologicheskie pamiatniki Nizhnego Podon'ia (Works of the Tsimliansk Expedition. Archaeological Monuments of the Lower Don Region) 1. Moscow: "Nauka-VL" Publ., 21-121. (in Russian).

Myskov, E. P., Kiyashko, A. V., Skripkin, A. S. 1999. In Skripkin, A. S., Yablonsky, L. T. (ed.). Nizhnevolzhskii arkheologicheskii vestnik (Lower Volga Archaeological Bulletin) 2. Volgograd: Volgograd State University, 149-167 (in Russian). 
Nikitina, G. F. 1988. In Kropotkin, V.V. (ed.). Mogil'niki cherniahovskoi kul'tury (Burial Grounds of the Chernyakhov Culture) 2. Moscow: "Nauka" Publ., 5-97 (in Russian).

Nikitina, G. F. 2008. Cherniahovskaia kul'tura Podnestrov'ya (po rezul'tatam analiza arheologicheskikh istochnikov) (Chernyakhov Culture of the Dniester Region (According to analysis of archaeological sources)). Moscow: "Taus" Publ. (in Russian).

1897. In Otchet Arkheologicheskoi komissii za 1895 g. (Report of the Archaeological Commission from 1895). Saint Petersburg (in Russian).

Petrenko, V. A. 1992. In Skripkin, A. S. (ed.). Problemy khronologii sarmatskoi kul'tury (Issues of the Chronology of Sarmatian Culture). Saratov: Saratov University, 32-45 (in Russian).

Pletneva, S. A. 1967. Ot kochevii k gorodam. Saltovo-maiatskaia kul'tura (From Camps to Towns. Saltovo -Mayaki Culture). Materialy i issledovaniia po arkheologii (Proceedings and Research in Archaeology of the USSR) 142. Moscow: "Nauka" Publ. (in Russian).

Pletneva, S. A. 1989. Na slaviano-khazarskom pogranich'e. Dmitrievskii arkheologicheskii kompleks (In the Slavic-Khazar Borderlands. Dmitriev Archaeological Complex). Moscow: "Nauka" Publ. (in Russian).

Puzdrovskii, A. E. 2007. Krymskaia Skifiia II v. do n. e. - III v. n. e. Pogrebal'nye pamiatniki (Crimean Scythia of the $2^{\text {nd }}$ Century $B C-3^{\text {rd }}$ Century AD. Funerary Sites). Simferopol: "Biznes-Inform" Publ. (in Russian).

Puzdrovskii, A. E. 2007. In Zuev, V. Yu. (ed.). Bosporskii fenomen: sakralnyi smysl regiona, pamiatnikov, nakhodok (The Bosporan Phenomenon: the sacred meaning of the region, monuments, finds). Saint Petersburg: State Hermitage, 278-285 Publ. (in Russian).

Puzdrovskii, A. E. 2005-2009. In Stratum plus. Archaeology and Cultural Anthropology (4), 329-338 (in Russian).

Puzdrovskii, A. E., Trufanov, A. A. 2017a. Polevye issledovaniia Ust'-Al'minskogo nekropolia v 2000-2003 gg. (Field Studies of the Ust-Alminsky Necropolis in 2000-2003). Simferopol, Moscow: Tipografiia IP Zueva T.V. Publ. (in Russian).

Puzdrovskii, A. E., Trufanov, A. A. 2017b. Polevye issledovaniia Ust'-Al'minskogo nekropolia v 20042007 gg. (Field Studies of the Ust-Alminsky Necropolis in 2004-2007). Simferopol, Moscow: Tipografiia IP Brovko Publ. (in Russian).

Puzdrovskii, A. E., Trufanov, A. A., Yurochkin, V. Yu. 2007. In Myts, V. L. (ed.). Arkheologicheskie issledovaniia v Krymu 1995 g. (Archaeological Studies in Crimea. 1995). Simferopol: "Sonat” Publ., 117-125 (in Russian).

Raev, B .A. 1993. In Antichnyi mir i arkheologiia (Ancient World and Archaeology) 9, 160-175 (in Russian).

Raev, B .A. 2006. In Klepikov, V. M. (ed.). Rannesarmatskaya i srednesarmatskaya kul'tury. Problemy sootnosheniya (Early Sarmatian and Middle Sarmatian Cultures. Issues of Relation) 2. Volgograd: Volgograd State University, 91-100 (in Russian).

Ryzhova, L. A. 1998. In Khersonesskii sbornik (Chersonesos collection). XIV. 283-290. (in Russian).

Sattarov R.R. In 2017. In Kamaleev, E. V. (ed.). Etnosy i kultury Uralo-Povolzhia istoriia i sovremennost' (Ethnis Groups and Cultures of the Ural-Volga Region: History and Modernity). Ufa: "Institute of Ethnological Studies" Publ., 103-106 (in Russian).

Sattarov, R. R. 2019. Importnye predmety v p'ianoborskoi kul'ture (konec II v. do n.e. - II v. n.e.) (Imported Items in the Piany Bor Culture (Late $2^{\text {nd }}$ century $B C-2^{\text {nd }}$ century $\left.A D\right)$ ). Diss of candidate of historical Sciences. Kazan (in Russian).

Sergatskov, I. V. 1999. In Skripkin, A. S. (ed.). Arkheologiia Volgo-Ural'skogo regiona v epokhu rannego zheleznogo veka i srednevekov'ia (Archaeology of the Volga-Ural Region in the Early Iron Age and the Middle Ages). Volgograd: Volgograd State University, 137-155 (in Russian).

Sergatskov, I. V. 2000. Sarmatskie kurgany na Ilovle (Sarmatian Barrows on the Ilovlya River). Volgograd: Volgograd State University (in Russian).

Sergatskov, I. V. 2000b In In Skripkin, A. S. (ed.). Nizhnevolzhskii arkheologicheskii vestnik (Lower Volga Archaeological Bulletin) 3. Volgograd: Volgograd State University, 113-122 (in Russian).

Sergatskov, I. V. 2004. In Raev, B. A. (ed.). Sarmatskie kul tury Evrazii: problemy regional'noi khronologii (Sarmatian Cultures of Eurasia: Issues of Regional Chronology). Krasnodar: Kuban State University, 107-116. (in Russian).

Sergatskov, I. V., Dvornichenko, V. V., Demkin, V. A. 2001. In Sergatskov, I. V. (ed.). Materialy po arkheologii Volgo-Donskikh stepei (Materials on the Archaeology of the Volga-Don Steppes) 1. Volgograd: Volgograd State University, 13-63 (in Russian).

Sergatskov, I. V., Zakharov, P. E. 2006. In Rossiiskaia Arkheologiia (Russian Archaeology) (1), 117-123 (in Russian).

Simonenko, A. V. 2001. In Skripkin, A. S. (ed.). Nizhnevolzhskii arkheologicheskii vestnik (Lower Volga Archaeological Bulletin) 4. Volgograd: Volgograd State University, 92-106 (in Russian). 
Simonenko, A. V. 2006a. In Klepikov, V. M. (ed.). Rannesarmatskaya i srednesarmatskaya kul'tury. Problemy sootnosheniya (Early Sarmatian and Middle Sarmatian cultures. Issues of Relation) 2. Volgograd: Volgograd State University Publ., 101-117 (in Russian).

Simonenko, A. V. 2006b. In Simonenko, A. V. (ed.). Liber Archaeologicae. Krasnodar. 137-152. (in Russian).

Simonenko, A. V. 2010. Sarmatskie vsadniki Severnogo Prichernomor'ia (Sarmatian Riders of the Northern Black Sea Region). Saint Petersburg: "Nestor-Istoriia" Publ. (in Russian).

Simonenko, A. V. 2011. Rimskii import u sarmatov Severnogo Prichernomor'ia (Roman Import of the Sarmatians from the Black Sea Region). Saint Petersburg: Faculty of Filology, Saint Petersburg State University (in Russian).

Sinitsyn, I. V. 1959. In Krupnov, E. I. (ed.). Materialy i issledovaniia po arkheologii SSSR (Materials and Research in Archaeology USSR) 60. Moscow: Academy of Sciences of the USSR, 39-205 (in Russian).

Sinitsyn, I. V. 1960. In Krupnov, E. I., Smirnov, K. F. (eds.). Materialy i issledovaniia po arkheologii SSSR (Materials and Research in Archaeology USSR) 78. Moscow: Academy of Sciences of the USSR, 10-108 (in Russian).

Skalon, K. M. 1961. In Artamonov, M. I. (ed.). Arkheologicheskii sbornik Gosudarstvennogo Ermitazha (Archaeological Bulletin of the State Hermitage Museum) 2. Leningrad: State Hermitage Museum, 114-140 (in Russian).

Skvortsov, N. B. 2017. In Drevnosti Volgo-Donskikh stepei (Antiquities of Volga-Don Steppes) 7. Volgograd: "Arkol” Publ., 43-71 (in Russian).

Skripkin, A. S. 1977. In Sovetskaya arkheologiya (Soviet archeology). (2). 100-120 (in Russian).

Skripkin, A. S. 1990. Aziatskaia Sarmatiia (problemy khronologii i ee istoricheskii aspekt) (Sarmatia Asiatica: Issues of Chronology and Its Historical Aspect). Saratov: Saratov University (in Russian).

Skripkin, A. S. 2000. In Myshkin, V. N. (ed.). Rannesarmatskaia kul tura: formirovanie, razvitie, khronologiia (Early Sarmatian Culture: Formation, Development, Chronology) Samara: Institute of Archaeology, Russian Academy of Sciences, 137-149 (in Russian).

Skripkin, A. S. 2005. In Belotserkovskaia, I. V. (ed.). II Gorodtsovskie chteniia. Materialy nauchnoi konferentsii, posviashchennoi 100-letiiu deiatel'nosti V.A. Gorodtsova v GIM. Aprel' 2003 g. (2nd Gorodtsov Readings. Proceedings of the Scientific Conference Dedicated to the 100th Anniversary of V.A. Gorodtsov in the National History Museum. April 2003). Series: Proceedings of the State Historical Museum 145. Moscow: State Historical Museum, 171-184 (in Russian).

Skripkin, A. S. 2006a. In Klepikov, V. M. (ed.). Rannesarmatskaya i srednesarmatskaya kul'tury. Problemy sootnosheniya (Early Sarmatian and Middle Sarmatian Cultures. Issues of Relation) 2. Volgograd: Volgograd State University Publ., 5-37 (in Russian).

Skripkin, A. S. 2006b. In Klepikov, V. M. (ed.). Rannesarmatskaya i srednesarmatskaya kul'tury. Problemy sootnosheniya (Early Sarmatian and Middle Sarmatian Cultures. Issues of Relation) 2. Volgograd: Volgograd State University, 135-137 (in Russian).

Skripkin, A. S., Mys'kov, E. P. 2009. In Makarov, N. A. (ed.). Arkheologicheskie otkrytiia 1991-2004 gg. (Archaeological Discoveries of 1991-2004. European Russia) Moscow: Institute of Archaeology, Russian Academy of Sciences, 245-255 (in Russian).

Smirnov, K. F. 1950. In Kratkie soobshcheniia Instituta istorii material'noi kul'tury (Brief Communications of the Institute for the History of Material Culture) XXXIV. Moscow, Leningrad: Academy of Sciences of the USSR, 97-114 (in Russian).

Smirnov, K. F. 1954. In Merpert, N. Ya. (ed.). Voprosy skifo-sarmatskoj arheologii (Issues of ScythianSarmatian Archaeology). Moscow: Academy of Sciences of the USSR, 195-219 (in Russian).

Smirnov, K. F. 1961. Vooruzhenie savromatov (Armament of the Sauromatians). Series: Materialy i issledovaniia po arkheologii SSSR (Materials and Studies in Archaeology of the USSR) 101. Moscow: Academy of Sciences of the USSR (in Russian).

Smirnov, K .F. 1974. In Sovetskaya arkheologiya (Soviet archeology). (3). 33-44 (in Russian).

Sorokina, N. P. 1965. In Shelov, D. B. (ed.). Drevnosti Nizhnego Dona (Antiquities of the Lower Don). Series: Materialy i issledovaniia po arkheologii SSSR (Materials and Studies in Archaeology of the USSR) 127. Moscow: "Nauka' Publ., 202-248 (in Russian).

Moshkova, M. G. (ed.). 2002. Srednesarmatskaya kul'tura (Middle Sarmatian culture). Series: Statisticheskaia obrabotka pogrebal'nykh pamiatnikov Aziatskoi Sarmatii (Statistical processing of funerary monuments of Asian Sarmatia). 3. Moscow: "Nauka' Publ. (in Russian).

Meliukova, A. I. (ed.). 1989. Stepi evropeiskoi chasti SSSR v skifo-sarmatskoe vremia (Steppes of the Eurasian Part of the USSR in the Scythian-Sarmatian Period). Moscow: "Nauka" Publ. (in Russian).

Stoyanova, A. A. 2004. In Zinko, V. N. (ed.). Bosporskie issledovaniia (Bosporan Studies) V. Simferopol; Kerch, 263-320 (in Russian).

Stoyanova, A. A. 2005. In Arkheologiia (Archaeology). (2), 47-54. (in Ukranian). 
Stoyanova, A. A. 2006d. Namisto i pidviski naselennia Krimu III st. do n. e. - IV st. n.e. (Beads and Pendants of the Population of Crimea in the $3^{\text {rd }}$ Century $B C-4^{\text {th }}$ Century AD). Diss of candidate of historical Sciences. Research Archive of the Institute of Archeology of the National Academy of Sciences of Ukraine. Found 12, doisser 850 (in Ukranian).

Stoyanova, A. A. 2012. Detskie pogrebeniia iz mogil'nika Opushki (po rezul'tatam raskopok 2003-2009 gg.) (Children's Burials from the Opushki Burial Ground (Based on the Results of Excavations in 2003-2009)). Simferopol: "Dolia" Publ. (in Russian).

Stoyanova, A. A. 2019. In Khrapunov, I. N. (ed.). Krym v sarmatskuyu epokhu (The Crimea in the Age of the Sarmatians (200 BC-400 AD)) 5. Simferopol: "Firma "Salta" LTD" Publ., 253-266 (in Russian).

Symonovich E. A. 1983. Naselenie stolicy pozdneskifskogo carstva (po materialam Vostochnogo mogil'nika Neapolya skifskogo) (Population of the Capital of the Late Scythian kingdom (Based on the Materials from the Eastern Scythian Burial Ground of Naples)). Kiev: "Naukova dumka" Publ. (in Russian).

Toshchev, G. N., Sapozhnikov, I. V. 1990. In Toshchev, G. N., Shakhrov, G. I., Shapovalov, G. I. (eds.). Drevnosti stepnogo Prichernomor'ia i Kryma (Antiquities of the Steppe Black Sea Region and Crimea). Zaporozh'e, 13-30 (in Russian).

Treister, M. Yu. 2008. Zuev, V. Yu. (ed.). In Bospor i Severnoe Prichernomor'e v antichnuiu epokhu (The Bosporus and the Northern Black Sea Region under in Ancient Age). Saint Petersburg: "Nestor-Istoriia" Publ., 146-160. (in Russian).

Treister, M. Yu. 2010. In Maslennikov, A. A. (ed.). Drevnosti Bospora (Antiquities of the Bosporus) 14. Moscow: Institute of Archaeology, Russian Academy of Sciences, 484-561. (in Russian).

Treister, M. Yu. 2014. In Zuev, V. Yu., Khrshanovski, V. A. (eds.). Pogrebal'naja kul'tura Bosporskogo carstva (Sepulchral culture of the Bosporan kingdom) Saint Petersburg: Nestor-Istoriia" Publ., 54-65 (in Russian).

Treister, M. Yu. 2018a. In Maslennikov, A. A. (ed.). Drevnosti Bospora (Antiquities of the Bosporus) 22. Moscow: Institute of Archaeology, Russian Academy of Sciences, 216-238. (in Russian).

Treister, M. Yu. 2018b In Materialy po istorii antichnogo i srednevekovogo Kryma (Materials on the history of ancient and medieval Crimea) 10. Sevastopol; Tyumen, 118-210 (in Russian).

Treister, M. Yu. 2019a. In Problemy istorii, filologii, kul'tury (Journal of Historical, Philological and Cultural Studies) (1), 25-68. (in Russian).

Treister, M. Yu. 2019b. In Vestnik drevnei istorii (Journal of Ancient History) (2). 379-415 (in Russian).

Treister, M. Yu. 2019 v. In Khrapunov, I. N. (ed.). Krym v sarmatskuyu epokhu (The Crimea in the Age of the Sarmatians (200 BC-AD 400)) 5. Simferopol: "Firma "Salta" LTD" Publ., 272-281 (in Russian).

Treister, M. Yu. 2020a. In Maslennikov, A. A. (ed.). Drevnosti Bospora (Antiquities of the Bosporus) 25. Moscow: Institute of Archaeology, Russian Academy of Sciences, 384-406 (in Russian).

Treister, M. Yu. 2020a. In Problemy istorii, filologii, kul'tury (Journal of Historical, Philological and Cultural Studies) (2), 5-60. (in Russian).

Treister, M. Yu. 2020v. In Problemy istorii, filologii, kul'tury (Journal of Historical, Philological and Cultural Studies) (3), 5-48. (in Russian).

Treister, M. Yu. 2020g. In Problemy istorii, filologii, kul'tury (Journal of Historical, Philological and Cultural Studies) (4), 41-109. (in Russian).

Troitskaya, T. N. 1957. In Shults, P. N. (ed.). Istoriia i arkheologiia Drevnego Kryma (History and Archaeology of Ancient Crimea). Kiev: Academy of Sciences of the Ukrainian SSR Publ., 174-190 (in Russian).

Trufanov, A. A. 2003/2004. Kukoval'skaia, N. M. (ed.). Sugdeiskii sbornik (Sugdaia Collected Works). Kiev, Sudak: "TOV Gorobets"” Publ., 495-521. (in Russian).

Trufanov, A. A. 2004a. In Rossiiskaia Arkheologiia (Russian Archaeology) (3), 160-170 (in Russian).

Trufanov, A. A. 2004b. In Koltukhov, S. G. (ed.). U Ponta Evklinskogo (pamiati P.N. Shultsa) (At Pontus Euxinum). Simferopol: Institute of Archaeology, National Academy of Sciences of Ukraine, 135-138 (in Russian).

Trufanov, A. A. 2007. In Zaitsev, Yu. P., Mordnitseva, V. I. (eds.). Drevniaia Tavrika. Posviashchsaetsia 80-letiyu T.N. Vysotskoi (Ancient Tavrika. Dedicated to the 80th Anniversary of T.N. Vysotskaya) Simferopol: "Univercum" Publ., 173-186 (in Russian).

Trufanov, A. A. 2001. In Gushchina, I. I., Zhuravlev, D. V.(eds.). Pozdnie skify Kryma. Pamiati N.A. Bogdanovoi (The Late Scythians in the Crimea). Series: Proceedings of the State Historical Museum 118. Moscow: State Historical Museum, 71-77 (in Russian).

Trufanov, A. A. 2005-2009. In Stratum plus. Archaeology and Cultural Anthropology (4), 117-328 (in Russian).

Trufanov, A. A. 2011. In Stratum plus. Archaeology and Cultural Anthropology (4), 223-270 (in Russian).

Trufanov, A. A., Mordvintseva, V. I. 2016. In Problemy istorii, filologii, kul tury (Journal of Historical, Philological and Cultural Studies) (2), 196-212. (in Russian).

Fedorov-Davydov, G. A. 1996. In Rossiiskaia Arkheologiia (Russian Archaeology) (1), 215-221 (in Russian). 
Khabdulina, M. K. 1994. Stepnoe Priishim'e v epokhu rannego zheleza (Steppe Ishim River Area in the Early Iron Age). Almaty: "Rakurs" Publ. (in Russian).

Khazanov, A. M., Chernenko, E. V. 1979. In Arkheologiia (Archaeology) 30, 18-26 (in Ukranian).

Khomyakova, O. A. 2018. In Oblomsky, A. M. (ed.). Brianskii klad ukrashenii s vyemchatoi emal'iu vostochnoevropeiskogo stilia (III v. n.e.) (Bryansk Hoard of Adornments with Champleve Enamel of Eastern European Style (3 ${ }^{\text {rd }}$ Century A.D.)). Series: Ranneslavianskii mir. Arkheologiia slavian i ikh sosedei (Early Slavic World. Archaeology of the Slavs and Their Neighbors) 18. Moscow - Vologda: Institute of Archaeology, Russian Academy of Sciences, "Drevnosti Severa" Publ., 86-94, fig. 69-79 (in Russian).

Khrapunov, I. N. 2002. Mogil'nik Druzhnoe (III-IV vv. nashei ery) (Druzhnoe Burial Ground ( $3^{r d}-4^{r d} c c$. $A D)$. Lublin: Wydaw. Uniw. M. Curie-Skłodowskiej (in Russian).

Khrapunov, I. N. 2006. In Materialy po arkheologii, istorii i etnografii Tavrii (Materials in the Archaeology, History and Ethnography of Tauria) 1 (12). 161-250 (in Russian).

Shabanov, S. B. 2015. In Problemy istorii, filologii, kul'tury (Journal of Historical, Philological and Cultural Studies) (3), 213-230. (in Russian).

Sharov, O. V. 2019 In Nizhnevolzhskii arkheologicheskii vestnik(Lower Volga Archaeological Bulletin) 18 (2), 197-220 (in Russian).

Shevchenko, N. F. In Raev, B. A. (ed.). Drevnosti Kubani i Chernomor'ia (Antiquities of the Kuban and Black Sea). Krasnodar: "Skifskaia galereia" Publ., 38-198 (in Russian).

Shevchenko, N. F 2006. In Vestnik drevnei istorii (Journal of Ancient History) (1). 141-154 (in Russian).

Shevchenko, O. B. 2018. In Bruyako, I. V., Glavenchuk, A. V. (eds.). Antichnyi Nikonii i mir plemion Severo-Zapadnogo Prichernomor'ia (Antique Nikoniy and the World of the Tribes of the North-Western Black Sea Region). Odessa, 77-85 (in Ukranian).

Spelov, D. B. 1978. In Kratkie soobshcheniia Instituta arkheologii (Brief Communications of the Institute of Archaeology) 156. Moscow: "Nauka" Publ., 16-22 (in Russian).

Shinkar, O. A. 2006. In Murasheva, V. V. (ed.). Gorod i step' v kontaktnoy Evro-Aziatskoy zone (The city and the steppe in contact Eurasian spase). Moscow: "Numizmaticheskaya literatura" Publ., 57-59 (in Russian).

Shinkar, O. A. 2007. In Voprosy istorii i arkheologii Zapadnogo Kazakhstana (Issues of History and Archaeology of Western Kazakhstan) 1. 103-119 (in Russian).

Yurochkin, V. Yu., Trufanov, A. A. 2003. In Zolotarev, M. I. (ed.). Khersonesskii sbornik (Chersonesos collection). XII. Sevastopol. 199-128. (in Russian).

Yablonsky, L. T., Davis-Kimball, J., Demidenko, Yu.V. 1995. In Yablonsky, L. T. (ed.). Kurgany levoberezhnogo Ileka (Mounds of the left bank of Ilek). 3. Moscow: Institute of Archaeology, Russian Academy of Sciences, 9-47, 100-175. (in Russian).

Yatsenko, S. A. 2007. In Zuev, V. Yu. (ed.). Bosporskii fenomen: sakralnyi smysl regiona, pamiatnikov, nakhodok (The Bosporan Phenomenon: the sacred meaning of the region, monuments, finds). Saint Petersburg: State Hermitage Publ., 275-279 (in Russian).

Feugère, M. 1985. Les Fibules en Gaule Méridionale (de la conquête à la fin du V s. ap. J.-C.). Revue Archéologique de Narbonnaise. Suppl. 12. Paris: Centre National de la Recherche Scientifique (in French).

Istvánovits, E., Kulcsár, V. 2014. In Madyda-Legutko, R., Rodzieńska-Nowak, J. (eds.). Honoratissimum assensus genus est armis laudare. Kraków, 143-149. (in English).

Marčenko, I. I., Limberis, N. Ju. 2008. In Simonenko, A., Marčenko, I. I., Limberis, N. Ju. Römische Importe in sarmatischen und maiotischen Gräbern. Archäologie in Eurasien. B.25. Mainz: Ph. von Zabern, 265-402, Taf. 1-222. (in Deutch).

Raev, B. 1986. Roman Imports in the Lower Don Basin. BAR International series 278. Oxford: BAR.

Riha, E. 1979. Die Römischen Fibeln aus Augst und Kaiseraugst. Forschungen in Augst. Bd.3. Augst. (in Deutch).

Simonenko, A. V. 2008. In Simonenko, A., Marčenko, I. I., Limberis, N. Ju. Römische Importe in sarmatischen und maiotischen Gräbern. Archäologie in Eurasien. B.25. Mainz: Ph. von Zabern, 1-95, Taf. 1-168. (in Deutch).

Treister, M. 2004. In Chr.Tuplin (ed.). Pontus and the outside wordl. Studies in Black Sea History, Historiography and Archaeology. Series: Colloquia Pontica. 9. Leiden; Boston, 131-193. (in English).

\section{About the Author:}

Krasnopeorov Aleksander A. Candidate of Historical Sciences, Udmurtian Institute of History, Language and Literature. Lomonosov Str. 4, Izhevsk, 426004, Russian Federation; khaa@udm.ru

Статья поступила в журнал 01.02.2021 г. Статья принята к публикации 01.02.2021 г. 
Таблица. А. Находки бронзовых наконечников стрел в «позднем» (после III в. до н.э.) контексте

Finds of bronze arrowheads in the "late" (after the third century BC) context

\begin{tabular}{|c|c|c|c|}
\hline комплекс ${ }^{1}$ & тип наконечника & сопутствующие находки & ссылки на публикации \\
\hline $\begin{array}{l}\text { Алитуб, к.3 } \\
(\text { («рестовый»)/п.20 }\end{array}$ & $\begin{array}{c}\text { двухлопастная, } \\
\text { нижний край } \\
\text { обломлен } \\
\end{array}$ & $\begin{array}{c}\text { Зеркало с валиком по краю Скрипкин-4.7, } \\
\text { котел: Демиденко-№19, ножной браслет, серьги, } \\
\text { сковорода Е130/Айлесфорд }\end{array}$ & $\begin{array}{c}\text { Максименко, 1983, рис. 37: } \\
\text { 1-14; Захаров, 2000; Глебов, } \\
\text { Толочко, 2016, рис. 16, с. 57-№7 }\end{array}$ \\
\hline Алитуб, к.26/п. & $\begin{array}{l}\text { с выступающей } \\
\text { втулкой }\end{array}$ & $\begin{array}{c}\text { Ковш Е136/Сиссия (Raev, 1896, pl. 22: 2), } \\
\text { стеклянная тарелка миллефиори, зеркало с } \\
\text { валиком по краю и выпуклостью в центре } \\
\text { Скрипкин-6.7, серьги, флакон, бусы: } \\
\text { Алексеева-78, гагатовая Бес, монеты Динамии. }\end{array}$ & $\begin{array}{c}\text { Засецкая, Ильюков, Косяненко, } \\
\text { 1999, рис. 1-4 }\end{array}$ \\
\hline Беляус, ск.1 & $\begin{array}{l}\text { с выступающей } \\
\text { втулкой }\end{array}$ & $\begin{array}{c}\text { Фибулы: ранне- и среднелатенские I серии } 1 \\
\text { варианта (Михлин, 1980, с. 195, 197, 201, рис. 1: } \\
\text { 1, 2: 3, 4: 5; Кропотов, 2010, с. 39-№ 7, 46-№29) }\end{array}$ & Пуздровский, 2007a, рис. 13: I \\
\hline $\begin{array}{l}\text { Бережновка II, } \\
\text { к. } 85 / \text { п. } 2\end{array}$ & $\begin{array}{c}\text { с выступающей } \\
\text { втулкой }\end{array}$ & $\begin{array}{c}\text { Бусы: треугольные полосатые подвески } \\
\text { Алексеева-193, «бусы-амфоры» Алексеева-193г }\end{array}$ & $\begin{array}{l}\text { Синицын, 1960, с. } 86, \text { рис. } 31: \\
\text { 3-5; Зуев, 1999, pис. } 4: 1-4 \text {, с. } \\
\text { 314-315 }\end{array}$ \\
\hline $\begin{array}{l}\text { Бережновка II, } \\
\text { к. } 100\end{array}$ & $\begin{array}{c}\text { с выступающей } \\
\text { втулкой }\end{array}$ & & $\begin{array}{c}\text { Синицын, } 1960 \text {, с. 100-101, рис. } \\
38: 1,3,5,39: 1,2\end{array}$ \\
\hline $\begin{array}{l}\text { Бережновка ЮЗГ, } \\
\text { к.1/п.11 }\end{array}$ & $\begin{array}{c}\text { двухлопастная с } \\
\text { шипом } \\
\end{array}$ & Меч с серповидным навершием & $\begin{array}{c}\text { Синицын, 1959, с. 115-116, рис. } \\
\text { 29: 5, 37: 2-6,21 }\end{array}$ \\
\hline Битак, ск.97 & $\begin{array}{c}\text { со скрытой } \\
\text { втулкой }\end{array}$ & $\begin{array}{c}\text { Фибула: лучковая } 1 \text { серии } 1 \text { варианта (Кропотов, } \\
\text { 2010, с. 83-№78), наконечник ножен, навершие- } \\
\text { рогатка, застежка с неподвижным крючком, } \\
\text { веретеновидный унгвентарий }\end{array}$ & $\begin{array}{c}\text { Зайцев, Мордвинцева, 2003, с. } \\
\text { 136, рис. 3: 6, 4: 2,4,6,7,23, 5: } \\
\text { 1,13-15,24, 7: 4, 9; Пуздровский, } \\
\text { 2007a, рис. } 34\end{array}$ \\
\hline Битак, ск.160 & $\begin{array}{l}\text { с выступающей } \\
\text { втулкой }\end{array}$ & $\begin{array}{c}\text { только текстовый перечень: зеркала- } \\
\text { подвески, лучковая фибула 2-3 варианта, } \\
\text { сильнопрофилированная фибула, игольник } \\
\text { (Труфанов, 2005-2009, с. 316) }\end{array}$ & $\begin{array}{c}\text { Пуздровский, 2007а, рис. 92: 2; } \\
\text { Труфанов, 2005-2009, рис. 87: } \\
3-4\end{array}$ \\
\hline $\begin{array}{l}\text { Вербовский II, } \\
\text { к.8/п.1 }\end{array}$ & $\begin{array}{c}\text { с выступающей } \\
\text { втулкой }\end{array}$ & Пряжки: круглые & $\begin{array}{l}\text { Мамонтов, 2008, pис. } 2: 5,5: 1 \text {, } \\
6: 5,14,16-26\end{array}$ \\
\hline Донской, к.6 $6^{2} / п .23$ & $\begin{array}{c}\text { с выступающей } \\
\text { втулкой }\end{array}$ & $\begin{array}{l}\text { Меч с кольцевым навершием, кольцевая застежка } \\
\text { с неподвижным крючком }\end{array}$ & Максименко, 1983, рис. 40: 1-6 \\
\hline Дружное, м. 4 & $\begin{array}{c}\text { двухлопастная с } \\
\text { шипом }\end{array}$ & $\begin{array}{c}\text { Пряжки Малашев-П2а, П10, наконечники ремней } \\
\text { с цилиндрическим расширением Малашев-Н10, } \\
\text { бусы, стеклянные сосуды }\end{array}$ & $\begin{array}{c}\text { Храпунов, 2002, с. } 46, \text { рис. } 75: \\
17\end{array}$ \\
\hline Дружное, м. 58 & $\begin{array}{l}\text { с выступающей } \\
\text { втулкой }\end{array}$ & $\begin{array}{c}\text { Пряжки Маалшев-П10, с круглой рамкой, сильно } \\
\text { выступающим язычком, круглым щитком, бусы, } \\
\text { подвески-топорики, подвески с выпуклинами }\end{array}$ & $\begin{array}{c}\text { Храпунов, 2002, с. } 46, \text { рис. } 143: \\
6\end{array}$ \\
\hline Дружное, м. 64 & $\begin{array}{c}\text { со скрытой } \\
\text { втулкой }\end{array}$ & Пряжка Малашев-П10, бусы, стеклянные сосуды & $\begin{array}{c}\text { Храпунов, 2002, с. } 46 \text {, рис. } 155: \\
10\end{array}$ \\
\hline Золотое, п.91 & $\begin{array}{c}\text { с выступающей } \\
\text { втулкой } \\
\end{array}$ & $\begin{array}{c}\text { Фибула: лучковая } 1 \text { серии } 2 \text { варианта (Кропотов, } \\
\text { 2010, с. 87-№142), бусы: фаянсовые львы }\end{array}$ & $\begin{array}{c}\text { Корпусова, 1983, табл. XXXIV: } \\
1-12\end{array}$ \\
\hline $\begin{array}{l}\text { Казанская/ } \\
\text { Тифлисская, к.34 }\end{array}$ & $\begin{array}{c}\text { трехлопастная с } \\
\text { шипом }\end{array}$ & & $\begin{array}{c}\text { Гущина, Засецкая, 1994, кат. 96- } \\
\text { 97, табл. } 10\end{array}$ \\
\hline $\begin{array}{l}\text { Казанская/ } \\
\text { Тифлисская, к.42 }\end{array}$ & $\begin{array}{c}\text { двухлопастная с } \\
\text { шипом } \\
\end{array}$ & Ручка таза E99/100, Пряжка: Малашев-П1 & $\begin{array}{c}\text { Гущина, Засецкая, 1994, кат. } \\
\text { 107-110, табл. } 11 \\
\end{array}$ \\
\hline $\begin{array}{l}\text { Казанская/ } \\
\text { Тифлисская, к.44 }\end{array}$ & $\begin{array}{c}\text { с выступающей } \\
\text { втулкой }\end{array}$ & Таз E100 & $\begin{array}{c}\text { Гущина, Засецкая, 1994, кат. } \\
120-126, \text { табл. } 13 \\
\end{array}$ \\
\hline $\begin{array}{l}\text { Казанская/ } \\
\text { Тифлисская, к.50 }\end{array}$ & $\begin{array}{c}\text { двухлопастная с } \\
\text { шипом }\end{array}$ & & $\begin{array}{c}\text { Гущина, Засецкая, 1994, кат. } \\
153-155, \text { табл. } 15,16\end{array}$ \\
\hline $\begin{array}{l}\text { Капак-Таш, к.1/кам. } \\
\text { ск./п.3 }\end{array}$ & $\begin{array}{l}\text { со скрытой } \\
\text { втулкой }\end{array}$ & $\begin{array}{c}\text { Фибулы: лучковая II серии } 4 \text { варианта (Кропотов, } \\
\text { 2010, с. 150-№179), среднелатенской схемы II } \\
\text { серии } 1 \text { варианта (Кропотов, 2010, с. 53-№41), } \\
\text { застежки с неподвижным крючком, бусы: } \\
\text { треугольные полосатые подвески Алексеева-193 }\end{array}$ & $\begin{array}{c}\text { Зайцев, 1999, рис. 6: 1; } \\
\text { Пуздровский, 2007a, рис. 53-56 }\end{array}$ \\
\hline Кобяково, п.329 & $\begin{array}{c}\text { с выступающей } \\
\text { втулкой }\end{array}$ & Зеркало-подвеска Скрипкин-6.10 & $\begin{array}{c}\text { Ларенок, 2013, табл. } 144: 3-7, \\
\text { c. } 230\end{array}$ \\
\hline Койсуг, к.4/п.32 & $\begin{array}{c}\text { двухлопастная с } \\
\text { шипом }\end{array}$ & $\begin{array}{c}\text { Пряжка, близкая типу Раддац-U, короткий меч без } \\
\text { навершия }\end{array}$ & $\begin{array}{l}\text { Максименко, } 1970 \text {, рис. } 1: 4,2: \\
\text { 4-9, 4: 1, с. 228; } 1983 \text {, рис. } 38: \\
7-15\end{array}$ \\
\hline
\end{tabular}




\begin{tabular}{|c|c|c|c|}
\hline Кос-Оба, к.2 & & $\begin{array}{c}\text { Памятник не издан. Только текстовый перечень: } \\
\text { диагональное погребение, } 18 \text { железных } \\
\text { черешковых, } 1 \text { бронзовый втульчатый наконечник, } \\
\text { зеркало «бактрийского» типа (с валиком по краю } \\
\text { и выпуклостью в центре диска), алебастровый } \\
\text { сосудик, стеклянные бусы, «комплекс следует } \\
\text { отнести не позднее I в. до н.э.» (Мошкова, 2004, } \\
\text { с. } 30,31) \text {. Дана ссылка на рис.3, но без точной } \\
\text { позиции. Под описание ничего не подходит }\end{array}$ & \\
\hline Курское, п.21 & $\begin{array}{c}\text { двухлопастная с } \\
\text { шипом } \\
\end{array}$ & Пряжка: Малашев-П2а & $\begin{array}{c}\text { Труфанов, 2003/2004, с. 510-511, } \\
\text { рис. } 10\end{array}$ \\
\hline Лехкч-Корт, п.1 & $\begin{array}{c}\text { с выступающей } \\
\text { втулкой }\end{array}$ & $\begin{array}{c}\text { Фибулы: лучковые III (Кропотов, 2010, с. 158- } \\
\text { №39-42), длинный меч с мергелевым навершием, } \\
\text { пряжки: круглые, Малашев-П7 } \\
\end{array}$ & $\begin{array}{l}\text { Виноградов, Петренко, } 1974, \\
\text { рис. } 2: 1-10, \text { с. } 171\end{array}$ \\
\hline Маляевка V, к.7/п.5 & $\begin{array}{c}\text { со скрытой } \\
\text { втулкой }\end{array}$ & $\begin{array}{c}\text { Меч с отломанной в древности рукояткой, } \\
\text { прямоугольный щиток железной пряжки } \\
\text { (Малашев-П1 - ?) }\end{array}$ & $\begin{array}{c}\text { Сергацков, Дворниченко, } \\
\text { Демкин, 2001, с. 20-21, рис. 4: } \\
\text { 5, 16: 4-6 }\end{array}$ \\
\hline Неаполь, п.3 & $\begin{array}{l}\text { двухлопастная с } \\
\text { шипом } \\
\text { с выступающей } \\
\text { втулкой }\end{array}$ & $\begin{array}{c}\text { Фибулы: лучковые } 1 \text { серии } 4 \text { варианта, II серии } \\
4 \text { варианта (Кропотов, 2010, с. 116-№174, 149- } \\
\text { №146), зеркала-подвески Скрипкин-6.10, браслет }\end{array}$ & $\begin{array}{c}\text { Сымонович, 1983, табл. IV: 7, } \\
\text { VII: 1, VIII: 8, XI: 18,19, XVI: } \\
\text { 1, XX-16, XXIV: 16,19, XXVIII: } \\
\text { 13,27, XXX: 3,6,11,35,42,53,67, } \\
\text { XXXI: 26,44, XXXII: 1, XXXIII: } \\
\text { 12, XXXIV: 15,24, XXXVI: } \\
\text { 11,12, XXXVIII: 19, XLII: 17,21, } \\
\text { XLIV: 2,12,13,26, XLVI: 3,9,11 }\end{array}$ \\
\hline Неаполь, п.39 & $\begin{array}{l}\text { с выступающей } \\
\text { втулкой } \\
\text { со скрытой } \\
\text { втулкой }\end{array}$ & $\begin{array}{c}\text { Фибула: среднелатенская II серии } 1 \text { варианта } \\
\text { (Кропотов, 2010, с. 52-№35), пластинчатые } \\
\text { поясные крючки }\end{array}$ & $\begin{array}{c}\text { Сымонович, 1983³ , табл. XIII: } \\
\text { 1, XIV: 1-5, XVI: 4,6,19,23,24, } \\
\text { XXI: 24, XXV: 1, XXIX: 11, } \\
\text { XXXIV: 17, XXXIX: 34, XLV: } \\
\text { 16; Зайцев, 1999, рис. 5: } 1\end{array}$ \\
\hline Неаполь, п.58 & $\begin{array}{c}\text { двухлопастная с } \\
\text { шипом }\end{array}$ & $\begin{array}{c}\text { Фибулы: лучковая II серии } 3 \text { варианта (Кропотов, } \\
\text { 2010, с. 143-№115), сложнопрофилированная } \\
\text { II серии (Кропотов, 2010, с. 234-№42), бусы: } \\
\text { фаянсовые бинокли, амулет-человечек, зеркало- } \\
\text { подвеска Скрипкин-6.10, браслет со змеиными } \\
\text { головками } \\
\end{array}$ & $\begin{array}{l}\text { Сымонович, 19834, табл. I: 13, } \\
\text { III: 10, II: 3, X: 5, XVI: 2, XVIII: } \\
\text { 20, XXVI: 28, XXVIII: 21, } \\
\text { XXIX: 21,33, XXXV: 25, XLII: 8, } \\
\text { XLIII: 32, XLIV: 20, XLV: } 1,12\end{array}$ \\
\hline Неаполь, ск.67 & $\begin{array}{c}\text { с выступающей } \\
\text { втулкой }\end{array}$ & $\begin{array}{c}\text { Рогатое навершие, застежки с неподвижным } \\
\text { крючком, наконечник ножен }\end{array}$ & $\begin{array}{l}\text { Сымонович, } 1983^{5} \text {, табл. IV: 6, } \\
\text { V: 7, VIII: 18, XVI: 5,13, XVII: 5, } \\
\text { XVIII: 5,19, XXIII: 36, XXVIII: } \\
\text { 18, XXIX: 3,10,27, XXX: 23,38, } \\
\text { XXXI: 5, XXXV: 9, XXVIII: 40, } \\
\text { XLV: 25,29,35 }\end{array}$ \\
\hline Неаполь, ск.96 & $\begin{array}{c}\text { с выступающей } \\
\text { втулкой }\end{array}$ & & Пуздровский, 2007a, рис. 92: 11 \\
\hline Неаполь, п.43 & $\begin{array}{c}\text { с выступающей } \\
\text { втулкой } \\
\end{array}$ & [никаких данных нет] & Пуздровский, 2007a, рис. 92: 1 \\
\hline Нейзац, п.164 & $\begin{array}{c}\text { двухлопастная с } \\
\text { шипом }\end{array}$ & Бусы & $\begin{array}{c}\text { Храпунов, 2006, рис. } 28,45: \\
6-12\end{array}$ \\
\hline $\begin{array}{l}\text { Нижнеарметовский, } \\
\text { кург. } 1977 \text { г. }\end{array}$ & двухлопастная & $\begin{array}{c}\text { Фибула: с завитком Амброз-13, сюльгама, пряжка: } \\
\text { Малашев-П2а, зеркало-подвеска Скрипкин-6.10 }\end{array}$ & Красноперов, Бахшиев, 2019 \\
\hline \begin{tabular}{l|} 
Никольское IV, \\
к.1/п.3
\end{tabular} & $\begin{array}{l}\text { с выступающей } \\
\text { втулкой }\end{array}$ & $\begin{array}{c}\text { Длинный меч без навершия, оселок, костяные } \\
\text { ворворки }\end{array}$ & $\begin{array}{c}\text { Дворниченко, Федоров- } \\
\text { Давыдов, 1989, с. 101-104, рис. } \\
\text { 28: в, 30, 31: 1 } \\
\end{array}$ \\
\hline Нимфей, К26 & $\begin{array}{c}\text { с выступающей } \\
\text { втулкой }\end{array}$ & $\begin{array}{c}\text { Фибула: лучковая фибула } 1 \text { серии } 4 \text { варианта } \\
\text { (Кропотов, 2010, с. 120-№303), навершие меча, } \\
\text { амулет-человечек, пряжки: круглые, зеркало с } \\
\text { плоским диском Скрипкин-1.4 или } 1.6\end{array}$ & $\begin{array}{c}\text { Грач, 1999, рис. 78-84, табл. } 175, \\
176\end{array}$ \\
\hline $\begin{array}{l}\text { Nyíregyháza- } \\
\text { Felsősima, NE of } \\
\text { Gyebras tanya, site } \\
161 \text {, grave } 280\end{array}$ & $\begin{array}{c}\text { со скрытой } \\
\text { втулкой }\end{array}$ & $\begin{array}{c}\text { Фибула: лучковая III серии (- ?), пряжка: Вадаи- } \\
\text { Кульчар-1, монета }\end{array}$ & Istvánovits, Kulcsár, 2014, fig. 1 \\
\hline $\begin{array}{l}\text { Новое Отрадное, } \\
\text { п.37 }\end{array}$ & & $\begin{array}{c}\text { Единственная находка в погребении, но памятник } \\
\text { хронологически монолитен }\end{array}$ & $\begin{array}{c}\text { Арсеньева, 1970, 107, рис. 12: } \\
17\end{array}$ \\
\hline $\begin{array}{l}\text { Октябрьский V, } \\
\text { к.1/п.1 }\end{array}$ & & $\begin{array}{c}\text { Канфар (скифос) Засецкая-Марченко-ІІІа, котел: } \\
\text { Демиденко-№159, железные и полихромные } \\
\text { («бирюзово-золотого стиля») пряжки: круглые, } \\
\text { удила, тазы, стакан, чаши, сосуд с зооморфной } \\
\text { ручкой. }\end{array}$ & $\begin{array}{c}\text { Мыськов, Кияшко, Скрипкин, } \\
\text { 1999, рис. 1-6; Скрипкин, } \\
\text { Мыськов, } 2009\end{array}$ \\
\hline
\end{tabular}




\begin{tabular}{|c|c|c|c|}
\hline Опушки, п.28 & $\begin{array}{c}\text { со скрытой } \\
\text { втулкой }\end{array}$ & Бусы: Алексеева-215-217 & Стоянова, 2012, рис. 17,18 \\
\hline $\begin{array}{l}\text { Панинардис, } \\
\text { п.2(К)/1972 }\end{array}$ & двухлопастная & $\begin{array}{c}\text { Зеркало с валиком по краю и небольшой } \\
\text { выпуклостью в центре Скрипкин-6.7, поясной } \\
\text { крючок, бусы, лапчатая подвеска }\end{array}$ & $\begin{array}{l}\text { Горбенко, Косяненко, 2011, рис. } \\
\text { 8-10 }\end{array}$ \\
\hline Покровка-2, к.9/п.1 & $\begin{array}{l}\text { со скрытой } \\
\text { втулкой }\end{array}$ & $\begin{array}{c}\text { Сбруйный набор, железные и бронзовые пряжки: } \\
\text { круглые, Малашев-П8, бронзовые наконечники }\end{array}$ & $\begin{array}{l}\text { Яблонский, Дэвис-Кимболл, } \\
\text { Демиденко, 1995, рис. 46, 47, } \\
\text { 62-71, с. 41-45 }\end{array}$ \\
\hline Сайхин СВ, к.1/п.5 & $\begin{array}{l}\text { со скрытой } \\
\text { втулкой }\end{array}$ & $\begin{array}{c}\text { только описание: } 2 \text { ножа (один согнут } \\
\text { вдвое), железная пряжка 8-видной формы с } \\
\text { неподвижным крючком, оселок }\end{array}$ & Синицын, 1959, с. 148, рис. 48: \\
\hline $\begin{array}{l}\text { Соколова Могила, } \\
\text { к. } 1 / \text { п.3 }\end{array}$ & $\begin{array}{l}\text { двухлопастная с } \\
\text { шипом }\end{array}$ & $\begin{array}{c}\text { Ойнохоя, канфар, ситула Е38*, браслеты, } \\
\text { ожерелья, фибулы, веер, фаянсовое блюдо в виде } \\
\text { раковины, стеклянная тарелка, и др. вещи. }\end{array}$ & $\begin{array}{l}\text { Ковпаненко, 1986; Симоненко, } \\
\text { 2011, кат. } 110 \text {, с. 220-225 }\end{array}$ \\
\hline $\begin{array}{l}\text { Суворовский, ск. } 38, \\
\text { между п. } 2 \text { и } 3\end{array}$ & $\begin{array}{l}\text { двухлопастная с } \\
\text { шипом }\end{array}$ & $\begin{array}{c}\text { Амфоры Шелов-F, Пряжки: Малашев-П10, } \\
\text { стеклянные сосуды, в т.ч. чаша типа Rau-Siger- } \\
\text { sted-Ganzkow (Шабанов, 2015), подвеска стиля } \\
\text { «Закшув-Кишпек», подвязная фибула Амброз } \\
\text { 16/3 - Гороховский-Б3б, зеркало с центральной } \\
\text { петлей, бусы, краснолаковые сосуды }\end{array}$ & $\begin{array}{c}\text { Юрочкин, Труфанов, 2003, } \\
\text { с. 204, 219, рис. 2: 23; } \\
\text { Пуздровский, Труфанов, } \\
\text { Юрочкин, 2007, с.120, рис. } 8: 14\end{array}$ \\
\hline $\begin{array}{l}\text { Тавельские курганы } \\
1897 \text { г. }\end{array}$ & $\begin{array}{l}\text { с выступающей } \\
\text { втулкой } \\
\text { со скрытой } \\
\text { втулкой }\end{array}$ & $\begin{array}{c}\text { Фибулы: с кнопкой } 1 \text { варианта (Кропотов, } \\
\text { 2010, с. 214-№18-19), двуигольная брошь } \\
\text { II серии со всадником, пружинная брошь, } \\
\text { лучковые } 1 \text { серии } 2 \text { варианта, детали уздечного } \\
\text { набора IV в. до н.э., поясные крючки, пряжки: } \\
\text { подковообразные (Труфанов, 2004а, с. 161, рис. } \\
\text { 1: 12-14), укороченные дугоконечные, браслеты } \\
\text { со змеиными головками, кольца с выступами, } \\
\text { монеты, одна из которых определена как } \\
\text { херсонесская III в. до н.э., кольца с выступами, } \\
\text { «кирки», перстень с закрученными концами }\end{array}$ & $\begin{array}{c}\text { Троицкая, 1957, №8-9, с. 184- } \\
\text { 189, рис. 10: 1, 11, 12; Труфанов, } \\
\text { 2004б; Пуздровский, 2007a, } \\
\text { рис.44, } 45\end{array}$ \\
\hline Танаис, п.1/Н3/1996 & $\begin{array}{c}\text { со скрытой } \\
\text { втулкой }\end{array}$ & Чернолаковая чашка 2-1 вв. до н.э. & Глебов, Толочко, 2016, рис. 3 \\
\hline Танаис, п.9/Н3/1996 & $\begin{array}{c}\text { двухлопастная с } \\
\text { шипом } \\
\end{array}$ & В заполнении ограбленного погребения & $\begin{array}{c}\text { Глебов, Ильяшенко, Толочко, } \\
\text { 2004, с. } 293 \\
\end{array}$ \\
\hline Тбилисская, к.9 & двухлопастная & $\begin{array}{c}\text { Фибулы: сложнопрофилированная II серии } \\
\text { (Кропотов, 2010, с. 236-№119), лучковая I серии } \\
3 \text { варианта (Кропотов, 2010, с. 105-№489), } \\
\text { «канделябр» }\end{array}$ & $\begin{array}{c}\text { Ждановский, } 1984, \text { с. 85-86, рис. } \\
2: 48-62\end{array}$ \\
\hline Тифлисская, к.20 & $\begin{array}{c}\text { двухлопастная с } \\
\text { шипом }\end{array}$ & $\begin{array}{c}\text { Бусы: фаянсовые львы, скарабеи, бинокли, } \\
\text { фаллосы, подвеска-котелок, подвески с } \\
\text { выпуклинами, ажурная подвеска }\end{array}$ & $\begin{array}{c}\text { Гущина, Засецкая, 1994, кат. } \\
\text { 310-328, табл. 33, } 34\end{array}$ \\
\hline $\begin{array}{l}\text { Торгунский I, } \\
\text { к.1/п.1 }\end{array}$ & $\begin{array}{c}\text { со скрытой } \\
\text { втулкой }\end{array}$ & $\begin{array}{c}\text { Фибула: лучковая } 1 \text { серии } 2 \text { варианта, бусы: } \\
\text { фаянсовые бинокли, скарабеи, треугольные } \\
\text { полосатые подвески }\end{array}$ & Демиденко, 2014, рис. 1-4 \\
\hline Усть-Альма, ск.43 & $\begin{array}{c}\text { с выступающей } \\
\text { втулкой }\end{array}$ & $\begin{array}{c}\text { Фибулы: лучковые } 1 \text { серии } 3 \text { варианта (Кропотов, } \\
\text { 2010, с. 94-№88), IV серии } 2 \text { варианта (Кропотов, } \\
\text { 2010, с. 163-№28), брошь формы } 8 \text { (Кропотов, } \\
\text { 2010, с. 318-№5), с завитком } 1 \text { серии (Кропотов, } \\
\text { 2010, с. 188-№66-67), бусы: Алексеева-78, } \\
\text { пряжки: подковообразные (Труфанов, 2004а, с. } \\
\text { 160, рис. 1: 8), Раддац-С, круглые, Малашев-П1, } \\
\text { зеркала-подвески Скрипкин-6.10, браслеты } \\
\text { со змеиными головками, ножной браслет, } \\
\text { ведерковидные подвески }\end{array}$ & Высотская, 1994, табл. 9-11 \\
\hline $\begin{array}{l}\text { Усть-Альма, } \\
\text { ск.92/п.16 }\end{array}$ & двухлопастная & $\begin{array}{c}\text { Фибулы: лучковые } 1 \text { серии } 2 \text { вариант (Кропотов, } \\
\text { 2010, с. 85-№43-49), II серии } 2 \text { варианта } \\
\text { (Кропотов, 2010, с. 137-№30-31), IV серии } 2 \\
\text { варианта (Кропотов, 2010, с. 163-№29), брошь } \\
\text { формы } 8 \text { (Кропотов, 2010, с. 318-№6), с завитком } \\
1 \text { серии (Кропотов, 2010, с. 188-№77-78), пряжки: } \\
\text { подковобразные (Труфанов, 2004а, с.161), } \\
\text { дугоконечные пряжки Раддац-С (Труфанов, } \\
\text { 2004а, с. 165, рис. 4: 5), круглые, бусы: фаянсовые } \\
\text { фаллосы, кукиши, грозди, скарабеи, кольца } \\
\text { с выступами, меч с кольцевым навершием, } \\
\text { ведерковидные подвески, ножной браслет, венок }\end{array}$ & $\begin{array}{l}\text { Высотская, 1994, табл. 29-31; } \\
\text { Труфанов, 2005-2009, рис. } 90\end{array}$ \\
\hline Усть-Альма, п.384 & $\begin{array}{c}\text { со скрытой } \\
\text { втулкой }\end{array}$ & & $\begin{array}{c}\text { Пуздровский, 2007a, рис. 92: 3, } \\
\text { 95: } 17\end{array}$ \\
\hline
\end{tabular}




\begin{tabular}{|c|c|c|c|}
\hline Усть-Альма, п.404 & $\begin{array}{l}\text { с выступающей } \\
\text { втулкой }\end{array}$ & $\begin{array}{c}\text { только текстовый перечень: зеркало с петелькой } \\
\text { Скрипкин-6.11, антропоморфные амулеты, } \\
\text { фаянсовые бусы, лучковые фибулы 2-3 вариантов, } \\
\text { кольцо с шишечками (Труфанов, 2005-2009, с. } \\
\text { 304) }\end{array}$ & $\begin{array}{c}\text { Пуздровский, 2007a, рис. 92: 4, } \\
128: 9\end{array}$ \\
\hline Усть-Альма, п.432 & $\begin{array}{c}\text { двухлопастная с } \\
\text { шипом }\end{array}$ & & $\begin{array}{c}\text { Пуздровский, 2007a, рис. 92: 9, } \\
\text { 147: 10,11, 148: } 6\end{array}$ \\
\hline $\begin{array}{l}\text { Усть-Альма, } \\
\text { ск. } 450 / п .5\end{array}$ & $\begin{array}{c}\text { с выступающей } \\
\text { втулкой }\end{array}$ & $\begin{array}{c}\text { только текстовый перечень: подвески-кирки, } \\
\text { фибула Авцисса, } 2 \text { лучковые фибулы, фибула с } \\
\text { завитком; под погр.4, перекрывает погр.24, 22-23, } \\
\text { 19-21 (Труфанов, 2005-2009, с. 305-306) } \\
\text { В склепе: лучковые фибулы } 1 \text { серии } 2 \text { варианта, II } \\
\text { серии } 2 \text { варианта, IV серии } 2 \text { варианта (Кропотов, } \\
\text { 2010, с. 85-№63-68, 137-№33-35, 163-№35-36), } \\
\text { фибулы-броши форм } 10 \text { и } 13 \text { (Кропотов, 2010, с. } \\
\text { 319-№4-5, 320-№1), фибула с завитком I серии } \\
\text { (Кропотов, 2010, с. 189-№105), фибула Авцисса, } \\
\text { форма } 2 \text { (Кропотов, 2010, с. 276-№21) }\end{array}$ & $\begin{array}{c}\text { Пуздровский, 2007a, рис. 92: 5, } \\
\text { 97: 3, 142: 2, 163: 1, 194: 5,11, } \\
\text { 197: 1,2,4, 198: 9-11; Труфанов, } \\
\text { 2005-2009, рис. 74: 47-65, 82: } \\
\text { 7-11 }\end{array}$ \\
\hline Усть-Альма, п.691 & $\begin{array}{l}\text { со скрытой } \\
\text { втулкой }\end{array}$ & $\begin{array}{c}\text { Фибула: сильнопрофилированная с расширенной } \\
\text { головкой, форма } 2 \text { (Кропотов, 2010, с. 262-№5), } \\
\text { бусы: фаянсовые амфоры, скарабеи, «кирки» }\end{array}$ & Труфанов, 2005-2009, рис. 84: 3 \\
\hline Усть-Альма, п.764 & $\begin{array}{c}\text { со скрытой } \\
\text { втулкой }\end{array}$ & $\begin{array}{c}\text { Неопределимый фрагмент лучковой фибулы, } \\
\text { фрагменты железных пряжек }\end{array}$ & $\begin{array}{l}\text { Пуздровский, Труфанов, 2017a, } \\
\text { рис. } 57\end{array}$ \\
\hline Усть-Альма, ск.777 & $\begin{array}{l}\text { с выступающей } \\
\text { втулкой }\end{array}$ & $\begin{array}{c}\text { Венки, наглазники и наротники, кольца с } \\
\text { выступами, пряжки: восьмерковидные Раддац-U } \\
\text { (Труфанов, 2004а, с. 164, 168, рис. 2: 8), } \\
\text { дугоконечные, вариант Б (Труфанов, 2004а, с. } \\
\text { 166, рис. 4: 2), мечи с кольцевым навершием, } \\
\text { без навершия с перекрестьем с изломом, псалии } \\
\text { с выступами, бусы: Алексеева-249, монета } \\
\text { (запаздывающая). }\end{array}$ & $\begin{array}{c}\text { Пуздровский, Труфанов, 2017a, } \\
\text { рис. 85-93 }\end{array}$ \\
\hline Усть-Альма, ск.844 & двухлопастная & $\begin{array}{c}\text { Бусы, подвески с выпуклинами, ойнохоя Е125/ } \\
\text { Милинген, кувшин «Стралджа», тарелка, патера } \\
\text { E155 или Nuber-G/Кентрбери }\end{array}$ & $\begin{array}{c}\text { Пуздровский, 2005-2009; } \\
\text { Пуздровский, Труфанов, 2017б, } \\
\text { рис. 28-32 }\end{array}$ \\
\hline Усть-Альма, п. 857 & $\begin{array}{c}\text { со скрытой } \\
\text { втулкой }\end{array}$ & $\begin{array}{c}\text { Фибула: лучковая } 1 \text { серии } 2 \text { варианта (Кропотов, } \\
\text { 2010, с. 86-№86), бусы: фаянсовые Бесы, } \\
\text { крапчатые»кирки», ножной браслет, подвески с } \\
\text { выпуклинами } \\
\end{array}$ & $\begin{array}{c}\text { Пуздровский, Труфанов, 2017б, } \\
\text { рис. 68-69 }\end{array}$ \\
\hline $\begin{array}{l}\text { Усть-Каменка, } \\
\text { к.71/п.1 }\end{array}$ & $\begin{array}{l}\text { со скрытой } \\
\text { втулкой }\end{array}$ & $\begin{array}{c}\text { Фибула: лучковая II серии } 2 \text { варианта (Кропотов, } \\
\text { 2010, с. 137-№17), бусы: фаянсовые бинокли, } \\
\text { Алексеева-486 }\end{array}$ & $\begin{array}{l}\text { Костенко, } 1993^{7} \text {, pис. 26: 1-17; } \\
\text { Simonenko, 2008, taf. 54: 1, kat. } \\
\text { 69; Симоненко, 2011, с. 193- } \\
\text { кат.65 }\end{array}$ \\
\hline $\begin{array}{l}\text { Усть-Лабинская, } \\
\text { к.35 }\end{array}$ & $\begin{array}{c}\text { двухлопастная с } \\
\text { шипом }\end{array}$ & $\begin{array}{c}\text { Бляшка «бирюзово-золотого стиля», } \\
\text { овальнорамчатая пряжка с прямой тыльной } \\
\text { стороной, близка типу Раддац-С }\end{array}$ & $\begin{array}{c}\text { Гущина, Засецкая, 1994, кат.395- } \\
\text { 403, табл.45 }\end{array}$ \\
\hline Чистенькое, к.1/п.2 & $\begin{array}{c}\text { со скрытой } \\
\text { втулкой }\end{array}$ & $\begin{array}{c}\text { Конские налобник и нащечники, удила с } \\
\text { крестовидными псалиями, трапециевидная } \\
\text { поясная застежка, меч с кольцевым навершием, } \\
\text { веретеновидный унгвентарий, крупные глазчатые } \\
\text { бусы: Алексеева-356, 386, ф19 }\end{array}$ & $\begin{array}{l}\text { Колтухов, Тощев, } 1998, \text { с. } 42-46, \\
\text { рис. } 21-22 \text {; Симоненко, } 2001, \\
\text { рис. } 1 \text {, с. } 92-94\end{array}$ \\
\hline Ясырев III, к.1/п.7 & $\begin{array}{c}\text { со скрытой } \\
\text { втулкой }\end{array}$ & Меч с кольцевым навершием & $\begin{array}{l}\text { Мошкова, Максименко, 1973, с. } \\
\text { 76, рис. 28: 6, 29: 10; Мошкова, } \\
\text { Фёдорова-Давыдова, 1974, с.68, } \\
\text { табл. XXIII: 8,9, XXV, XXVI, } \\
\text { XXVII: 2,5; Максименко, 1983, } \\
\text { рис. 36: } 1-4\end{array}$ \\
\hline $\begin{array}{l}\text { Беляус, гунн. } \\
\text { могила №3 }\end{array}$ & $\begin{array}{c}\text { двухлопастная с } \\
\text { шипом }\end{array}$ & $\begin{array}{c}\text { Серьги: с многогранником, калачевидная с } \\
\text { ребром, крученая гривна с петлями, В-образная } \\
\text { пряжка, колокольчик } \\
\end{array}$ & $\begin{array}{c}\text { Дашевская, 2003, рис. 2: 9; 2014, } \\
\text { табл. 174: } 9\end{array}$ \\
\hline Паласа-Сырт, к.2 & $\begin{array}{l}\text { с выступающей } \\
\text { втулкой }\end{array}$ & $\begin{array}{c}\text { Серьги с наборным многогранником со } \\
\text { стеклянными вставками, фибула: Амброз-15-4-1, } \\
\text { косметический прибор, игольник, ситечко, пряжка } \\
\text { с плоской рамкой, зеркало с петлей и звезчатым } \\
\text { рельефом Балта-Анке-3 }\end{array}$ & $\begin{array}{l}\text { Котович, 1959, табл. ХІІІ: 17; } \\
\text { Гмыря, 2011, рис. 7: } 4\end{array}$ \\
\hline Оселивка, п.51 & $\begin{array}{l}\text { с выступающей } \\
\text { втулкой }\end{array}$ & $\begin{array}{c}\text { Овальнорамчатая пряжка с прямым язычком без } \\
\text { уступа у основания, заходящим до середины } \\
\text { высоты рамки, гребень Никитина-III-В2б } \\
\text { (Никитина, 2008, рис. } 18: 2, \text { с. } 82,83 \text { ) }\end{array}$ & Никитина, 1988, табл. 27: 4 \\
\hline
\end{tabular}




\begin{tabular}{|l|c|c|c|}
\hline Фрикацей, к.6/п.1 & $\begin{array}{c}\text { двухлопастная с } \\
\text { шипом }\end{array}$ & $\begin{array}{c}\text { В заполнении входного колодца; полихромная } \\
\text { фибула }\end{array}$ & $\begin{array}{c}\text { Тощев, Сапожников, 1990, рис. } \\
5: 7\end{array}$ \\
\hline $\begin{array}{l}\text { Дмитриевский, } \\
\text { кат.26 }\end{array}$ & $\begin{array}{c}\text { двухлопастная с } \\
\text { шипом }\end{array}$ & & $\begin{array}{c}\text { Плетнева, 1967, с. 174, рис. 47: } \\
16 ; \text { Плетнева, 1989, рис. 58: 26 }\end{array}$ \\
\hline $\begin{array}{l}\text { Маяки, комплекс } \\
\text { неизвестен }\end{array}$ & $\begin{array}{c}\text { двухлопастная с } \\
\text { шипом }\end{array}$ & Михеев, 1985, рис. 16: 12 \\
\hline
\end{tabular}

${ }^{1}$ По поводу некоторых комплексов есть сомнения в датировании: Западные могилы, к.18/п.3 (Скворцов, 2017, c. 52, рис. 7: 5,11,13,16,17), Кривая Лука I, к.1/п.1 (Дворниченко, Малиновская, Федоров-Давыдов, 1977, с. 5-6, рис. 2, 59: 1, 88: 1, 91: 3), Амангельды, к.14/п.1 (Хабдулина, 1994, рис. 22: I), Первомайский VII, к.93/п.10-2 (Мамонтов, 2000, с. 42-43, рис. 20: 5-8, 27: 1). Детальной хронологии сарматской керамики не существует, а других находок нет. В Шебалино, к.3/п.7 (Мамонтов, 1995, с. 25-26, рис.1: 7, 5: 12-14) только мелкие фрагменты кинжала с прямым перекрестьем и глазчатая бусина. В Покровка 2, к.10/п.1,2 (Яблонский, Дэвис-Кимболл, Демиденко, 1995, рис. 48, 49, 71, 72) только стрелы.

${ }^{2}$ М.Г. Мошкова и В.Е. Максименко упоминают о наконечнике из Донской, к.5/п.23 (Мошкова, Максименко, 1973, c. 77).

${ }^{3}$ В описании погребения (с. 43-44) дана ссылка на фибулу табл. XXVI: 19, в подрисуночных подписях она отнесена к погр.75.

${ }^{4}$ В описании погребения (с. 67-68) дана ссылка на зеркало табл. XLII: 2, в подрисуночных подписях оно отнесено к погр.70.

${ }^{5}$ В описании погребения (с. 48-49) даны ссылки на следующие предметы: антропоморфную подвеску табл. XLV: 2, в подрисуночных подписях она отнесена к случайным находкам 1956 г; фибулу табл. XXVII: 20 - отнесена к погр.15; пронизку табл. XXIX: 13 - отнесена к погр.75; «пуговицу» табл. XXV: 29 - отнесена к погр.26. Пряжки табл. XXXIX: 5 нет в описании погребения.

${ }^{6}$ Вещи не изданы. В описании (Бабенчиков, 1957, с. 99) отмечено, что склеп датируется обломками керамики І в. н.э., и является наиболее ранним из раскопанных.

${ }^{7}$ Бусины рис. 26: 7 нет в описании погребения. 